\title{
IIIness-related absence among preschool children: Insights from a health intervention in Swedish preschools
}

\section{Caroline Hall Erica Lindahl}


The Institute for Evaluation of Labour Market and Education Policy (IFAU) is a research institute under the Swedish Ministry of Employment, situated in Uppsala. IFAU's objective is to promote, support and carry out scientific evaluations. The assignment includes: the effects of labour market and educational policies, studies of the functioning of the labour market and the labour market effects of social insurance policies. IFAU shall also disseminate its results so that they become accessible to different interested parties in Sweden and abroad.

Papers published in the Working Paper Series should, according to the IFAU policy, have been discussed at seminars held at IFAU and at least one other academic forum, and have been read by one external and one internal referee. They need not, however, have undergone the standard scrutiny for publication in a scientific journal. The purpose of the Working Paper Series is to provide a factual basis for public policy and the public policy discussion.

More information about IFAU and the institute's publications can be found on the website www.ifau.se

ISSN 1651-1166 


\title{
IIIness-related absence among preschool children: Insights from a health intervention in Swedish preschools ${ }^{a}$
}

\author{
by \\ Caroline Hall $^{\mathrm{b}}$ and Erica Lindahl ${ }^{\mathrm{c}}$
}

December 13, 2016

\begin{abstract}
We evaluate the effect of a preschool health intervention aimed at reducing infections through improved hygiene practices and training of the staff. The large-scale design enables us to study heterogeneous effects with respect to several child and preschool characteristics that are assumed to be associated with the initial level of absence, and thereby the potential magnitude of the effect. We find no reduction, on average, in children's illness-related absence. This conclusion holds across different age groups of preschool children, and for preschools with varying levels of absence before the intervention. However, we do find some evidence for a decline in illness-related absence among children enrolled in preschool sections with relatively few children. We find some empirical support for that the intervention consisted of components with opposing effects on illness-related absence, which may explain the zero average effect.
\end{abstract}

Keywords: Preschool, absence due to illness

JEL-codes: J13, J48

\footnotetext{
${ }^{a}$ We are grateful to Allison Aiello, Marianne Bengtsson, Marcus Eliason, Anna Sjögren and seminar participants at IFAU, Linnaeus University and the ESPE as well as the EALE annual conference 2016 for valuable comments. Financial support from Swedish Social Insurance Agency is gratefully acknowledged.

${ }^{\mathrm{b}}$ Institute for Evaluation of Labour Market and Education Policy (IFAU) and Uppsala Center for Labor Studies (UCLS); email: caroline.hall@ifau.uu.se.

c Institute for Evaluation of Labour Market and Education Policy (IFAU); email: erica.lindahl@ifau.uu.se.
} 


\section{Table of contents}

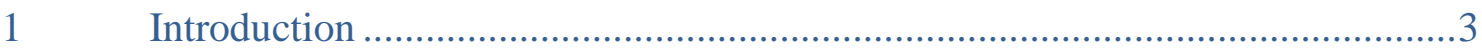

$2 \quad$ Early childhood education in Sweden ........................................................6

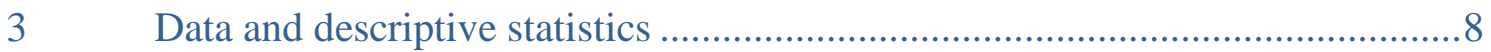

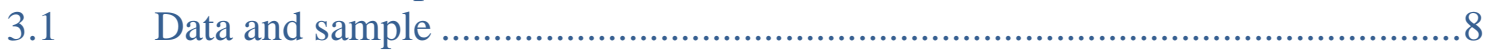

3.2 Absence due to illness among preschool children..........................................11

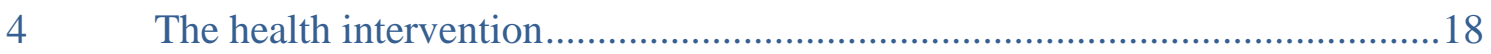

$5 \quad$ Estimating the effect of the health intervention ............................................20

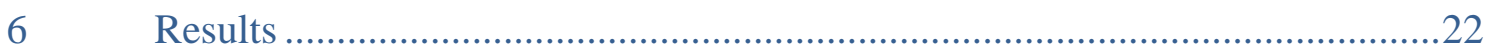

6.1 Estimated overall effect of the health intervention .........................................23

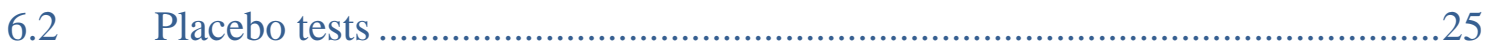

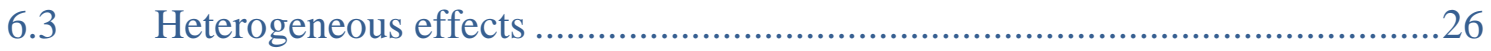

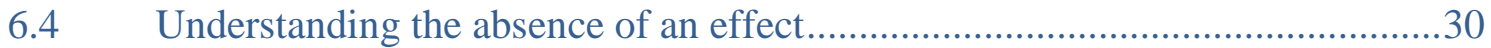

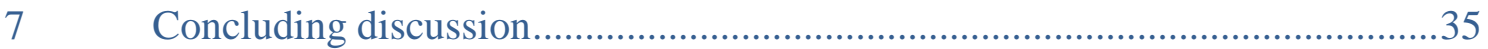

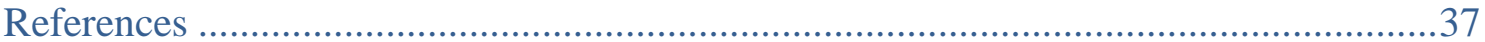

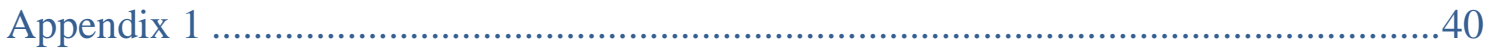

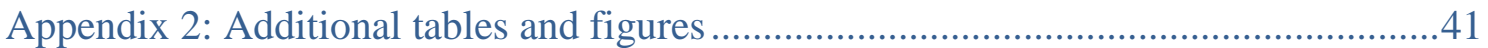




\section{Introduction}

Along with women's increased participation in the labor force, early childhood education and care services ${ }^{1}$ have expanded in many OECD countries. In several countries such as France, Germany, Sweden, and the UK more than 90 percent of all 3year-olds are enrolled in early childhood education (OECD 2014). While a number of studies have found positive impacts of early childhood education programs on both cognitive and non-cognitive outcomes ${ }^{2}$ (particularly for disadvantaged children), the picture is less positive when it comes to health benefits. Descriptive evidence demonstrates a substantially higher number of infections among children who attend preschool compared to children who are cared for in the home (see, e.g., Wald, Guerra and Byers 1991; Lu et al. 2004; and de Hoog et al. 2014), suggesting that preschool attendance at very young ages might be detrimental for child health, at least in the short run. Consistent with this, Baker, Gruber and Milligan (2008) find that an expansion of childcare in Quebec had negative effects on children's health status.

Whether, and to what extent, children's health is affected by preschool attendance may depend on the quality of the specific preschool center. In this paper we can show that there are large differences between preschools with respect to children's level of absence due to illness - conditional on parents' socio-economic background. This finding suggests that preschool quality and activities within preschools may be an important determinant of children's health outcomes.

The purpose of this paper is to investigate if improved hygiene practices at the preschool can reduce children's absence due to illness. To this end, we evaluate an intervention with the aim of reducing the number of infections among the children. The intervention, which took place in nearly all public preschools in Gothenburg municipality (the second largest municipality in Sweden), involved an inspection of the preschool's hygiene practices (e.g. hand hygiene, food handing and cleaning/surface disinfection), a lecture for the staff on how to prevent contagious illness among children, and guidelines regarding recommended length of absence for different types of infections. We evaluate the effect of the intervention on children's illness-related

\footnotetext{
${ }^{1}$ Throughout this paper we use the terms childcare, early childhood education, and preschool interchangeably as Sweden, like many other countries, use integrated programs.

${ }^{2}$ E.g. Berlinski, Galiani, and Gertler (2009); Havnes and Mogstad (2011); Gormley et al. (2005); and Dhuey (2011). An exception is Lefebvre, Merrigan, and Roy-Desrosiers (2011) who find negative effects on children's vocabulary from an expansion of childcare in Canada. See Ruhm and Waldfogel (2011) for a recent survey of the effects of early childhood education programs.
} 
absence. In order to further assess the potential for this type of policy initiative to reduce absence due to illness, we pay particular interest to whether the effect of the program varies with different child and preschool characteristics that may be important for children's amount of illness (e.g., child age, group size, age composition among the children, and initial hygiene conditions at the preschool).

There is limited knowledge about how illness-related absence varies across preschools with different (child and preschool) characteristics. We therefore also describe how (in our context) illness-related absence varies with the age of the children, and how much of the variation in absence levels across preschools that can be explained by differences in the children's background characteristics.

In addition to the suffering that illness brings on a child and the potential long-run health impact, ${ }^{3}$ there are several other costs associated with a child being ill: Parents may need to stay home from work in order to care for the child, implying lost earnings as well as potential production disruptions at the workplace. In Sweden, the social insurance system compensates parents for lost earnings due to care for an ill child. The state's expenditure for this type of benefit amounted to around SEK 5 billion (EUR 534 million) for 2013 (Swedish Social Insurance Agency 2014). The child's illness may also be contagious to other family members as well as to the preschool staff. Moreover, long or frequent absence spells may affect human capital accumulation as the child misses out of the educational content of the preschool program. In addition, the child may also miss out of important aspects of socialization and group belonging. Thus, there may be large economic gains from knowledge about how to organize and run preschools in order to minimize the risk that the preschool itself causes child illness.

Our study is based on detailed register data on preschool enrollment, which we have linked to daily information on parents' use of temporary parental benefits for care for an ill child as well as information from the preschools on the share of children absent due to illness. Our data also include a large number of background variables for the children and their parents. To estimate the causal effect of the intervention, we take advantage of the fact that it was rolled out gradually, district by district, during a six-year period. We

\footnotetext{
${ }^{3}$ While the economic literature tends to highlight the potential for childhood health investments to have positive long-term effects on individuals' health outcomes (e.g. Almond and Currie 2011), it is also possible that more infections during early childhood reduces the number of infections later on by strengthening the immune system (see e.g. Ball et al. (2002); de Hoog et al. 2014). A reduced number of infections during the first preschool year due to improved hygiene may then imply that the child instead experiences more infections later on.
} 
compare the rate of absence due to illness among children in preschools that have taken part of the intervention, with the absence rate among children in preschools that have not yet taken part, using a difference-in-differences design.

The youngest cohort of preschool children (1- to 2-year-olds) is reported ill about 12 percent of all days the preschool is open. Our data also reveal a strong age gradient in absenteeism: 1- to 2-year old preschool children are absent almost twice as much as 4to 5-year-olds. We find no reduction, on average, in children's illness-related absence due to the intervention. This conclusion holds regardless of whether we measure illnessrelated absence by parents' use of temporary parental benefits or as reported absence from the preschools. It also holds across different age groups of preschool children, and for preschools with varying absence levels before the intervention. However, we do find a small decline in the use of temporary parental benefits among children who attend sections with relatively few children. We find some empirical support for that the zero average effect may be the sum of two opposing effects: an initial increase possibly caused by stricter guidelines regarding absence during infections, followed by a decrease, possibly caused by improved hygiene practices. The decrease occurs after the assessment of the preschool's hygiene practices and a lecture for the staff, which is in line with improved hygiene leading to less absence due to illness among the children.

There are several previous studies of hygiene interventions at childcare centers, most of which are based on small-scale randomized control trials with monitored compliance of the stricter hygiene practices (see, e.g., Willmott et al. 2015; Brady 2005; and Huskins 2000 for reviews). Most studies report reduced rates of infections due to the interventions being studied. For instance, Lennell et al. (2008) find that the use of handdisinfection decreased children's rate of absenteeism due to infections by 12 percent in a group of Swedish preschools, and Uhari and Möttönen (1999) find an 8-9 percent reduction of the number of infections among Finnish preschool children following an educational prevention program.

This paper contributes to this literature by studying a large-scale ongoing intervention, involving altogether 275 preschools. There is generally a lack of evidence from large-scale hygiene interventions at preschools. This is unfortunate since it is doubtful whether the evidence from small-scale experiments with strict implementation and monitoring are applicable when interventions are introduced on a much larger scale and 
strict practices are to be maintained over time. We utilize daily data on children's absence due to illness for a sample of more than 20,000 children per year, and our data span a time period of eight years. Access to detailed data for such a large sample, enables us not only to estimate the average effect of the intervention, but also to investigate if the effect varies with either child or preschool characteristics. Such analyzes are important from a policy perspective as they show how one can target this type of interventions to settings where they are most likely to be effective. The data also allow us to estimate both the short- and the longer-run impact of the intervention.

Our paper also contributes to the economic literature on effects of early childhood education programs ${ }^{4}$, by investigating the importance of one aspect of preschool quality, namely hygiene practices, for children's health-related outcomes.

The rest of the paper is outlined as follows: We start by describing the Swedish preschool/childcare system (Section 2). Thereafter, we present our data and show descriptive statistics on absence due to illness among preschool children (Section 3). In Section 4 we describe the health intervention, and in Section 5 we outline how we identify its effect on illness-related absence. Section 6 presents our results and Section 7 concludes.

\section{Early childhood education in Sweden}

The labor force participation rate in Sweden is almost as high among women as among men, also among mothers with young children. ${ }^{5}$ The municipalities are obliged to provide preschool to all children from the age of 1 if the parents are working or studying. Nearly 50 percent of all 1-year-olds are enrolled in preschool and close to 90 percent of all 2-year-olds; see Figure 1. Most children stay enrolled until the age of 6 when they move on to a preschool class, which serves as a one-year bridge between preschool and compulsory school.

\footnotetext{
${ }^{4}$ See Ruhm and Waldfogel (2011) for an overview.

${ }^{5}$ According to official figures from the Swedish Labor Force Survey (AKU).
} 
Figure 1: Percentage of children of different ages who attend preschool, 2014

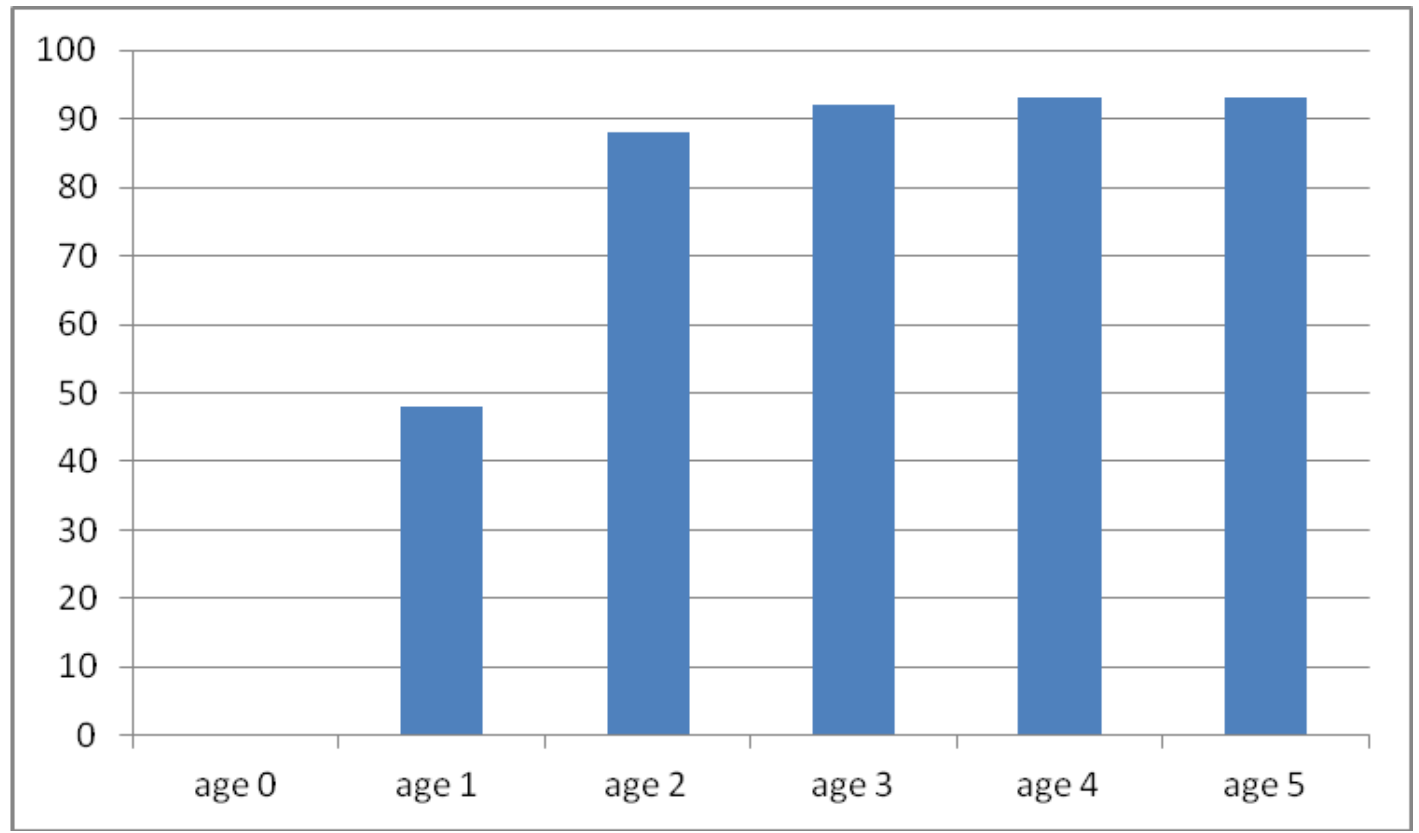

Source: National Agency for Education (2014)

Parents can request specific preschool centers. If there are no open slots at these centers, they will be offered a slot at a preschool as close as possible to their home. The preschool fee is highly subsidized and does not vary across centers: the fee is proportional to the parents' income (up to 3 percent of a family's monthly income), but will never exceed SEK 1,287 (EUR 136) per month. ${ }^{6}$ Families with more than one child enrolled pay a reduced fee per child. The maximum fees apply to both public and private preschools. Most preschools are publicly provided: in 2014, only around 20 percent of the children were enrolled at privately provided preschool centers (National Agency for Education 2014b).

Early childhood education and childcare is combined in Sweden. Preschools thus have the dual task of both enabling parents to combine parenthood with work (or studies) and to promote children's development and learning. ${ }^{7}$ Since 1998 there is a national curriculum that all preschools have to follow. Since early childhood education is explicitly promoted from young ages, children whose parents are unemployed or on parental leave with a younger sibling ${ }^{8}$ are also entitled to preschool, but for fewer hours

\footnotetext{
${ }^{6}$ These are the fees that applied in August 2015.

${ }^{7}$ Such integrated systems are also used in many other countries, e.g. in Norway, the Netherlands and the United States.

${ }^{8}$ Parents are (jointly) entitled to 450 days of paid parental leave per child. The parents can split these days as they like, with the exception of 60 days which are reserved for each parent. Parents with children under the age of 8 are
} 
per week (minimum 15 hours). Since 2010, all children are entitled to 15 hours of preschool free of charge from the fall semester of the year they turn 3.

The quality of early childhood education in Sweden appears to be high from an international perspective: In OECD's cross-country comparison of pupils to teaching staff ratios for 2012, only Iceland has a lower ratio than Sweden (OECD 2014). In 2014, the average number of children per preschool section was 16.9, and the average child/staff ratio was 5.3 (National Agency for Education 2014b). 43 percent of the staff had a tertiary teaching degree, and an additional 22 percent had completed an upper secondary degree for working with children.

When a child suffers from a contagious illness, he or she is not allowed to attend preschool, although the guidelines and practices regarding minor illness are likely to vary across preschools. As mentioned in the introduction, the social insurance system instead compensates parents for lost earnings due to care for an ill child. Parents are entitled to such temporary parental benefits (TPB) until the child turns 12 . These benefits are paid from the first day in an absence spell and the compensation is 77.6 percent of foregone earnings, up to a cap that corresponds to earnings in the $70^{\text {th }}$ percentile of the earnings distribution. The parents are jointly eligible for 120 days of TPB per child and year. After these 120 days, an additional 60 days can be used if approved by the Social Insurance Agency.

\section{Data and descriptive statistics}

\subsection{Data and sample}

For the purpose of this study we have compiled a unique data set on absence due to illness among preschool children, which we have linked to register data on preschool enrollment and a number of background variables for the children as well as their parents and siblings.

The enrollment data come from a register provided by the municipality of Gothenburg, and include all children enrolled in preschool within the municipality (as well as three smaller neighboring municipalities). The register contains information on the exact dates each child was enrolled, in what type of preschool (e.g. public or

also entitled to unpaid job-protected leave with a great portion of flexibility. During the child's first 18 months, both parents can stay at home from work on a full-time basis with job protection. 
private), in which specific preschool and in which specific section/group within the preschool. ${ }^{9}$ Since this is a universal register we can also use it to determine the number of children in each preschool and in each section of the preschool, as well as the age composition among the children in each section.

Using these data, we have created a panel of monthly information about each child enrolled in preschool, at any time, during 2005-2012. That is, a child enters the panel when he/she enrolls in preschool (or in 2005), and leaves the panel when he/she is no longer enrolled (or in 2012). Our sample consists of 2,587,860 child-by-month observations. The number of children included increases from 22,105 in 2005 to 27,491 in $2012 .^{10}$

We use two measures of absence due to illness obtained from different sources. We primarily rely on information about parents' use of temporary parental benefits (TPB) for care for an ill child from the Social Insurance Agency. This information is available the full sample of children in our data. The drawback with this measure is that it underestimates illness-related absence as parents do not always use these benefits: some parents may choose to work from home when their child is ill, some children may be cared for by someone else (e.g. a relative), and parents who do not work are not entitled to these benefits. ${ }^{11}$

Our second measure of illness-related absence is based on absence data collected from a sample of preschools, and should not suffer from underreporting. When the health intervention was introduced in Gothenburg in 2007, preschools were asked to start recording to what extent children were present at preschool or absent due to illness. They were also asked to register the type of illness the children suffered from (upper respiratory tract infections; diarrhea/vomiting; other infections, e.g. fever, eye infections, chickenpox; and non-contagious illness). These data, which are based on information provided by the parents, as they call in sick for their child, have been collected and digitalized at the preschool section level and are available for about 40 percent of the sample of children. ${ }^{12}$

\footnotetext{
${ }^{9}$ Information on preschool section is missing for about 2 percent of the sample. In these cases we treat the preschool as having just one section.

${ }^{10}$ Figures are from October each year.

${ }^{11}$ The exception is unemployed individuals who receive unemployment benefits; they are also entitled to TPB.

12 The summer months (June, July and August) are not included in these data since many preschools close during a part of the summer. ${ }^{13}$ This is the division used in the absence data from the preschools.
} 
The individual background variables come from various registers from Statistics Sweden and include information about sex, month of birth, and foreign background for each child. Using the birth register we have linked the children to their biological or legal parents as well as to their siblings, and added register information about the parents' labor market related outcomes. We have the following information about the parents: age, educational attainment (number of years of formal education), foreign background (born in another Nordic country or outside the EU), source of income, e.g. wage income or study grants. This latter information we use as a proxy for student status (all students in Sweden are entitled to study grants). Student status may be important to account for in the analysis as students are not entitled to TPB, which is our main measure of illness-related absence. In addition to the parental information, we have information about the month and year of birth of all siblings. Like student status, the presence of siblings may be important to account for as those who have younger children may be on parental leave and therefore not entitled TPB. Table 1 shows descriptive statistics for all background variables included in the dataset. 
Table 1: Descriptive statistics of all background variables

\begin{tabular}{|c|c|c|}
\hline Variable & Mean & $\begin{array}{l}\text { Standard } \\
\text { deviation }\end{array}$ \\
\hline \multicolumn{3}{|l|}{ A. Individual background information: } \\
\hline Age (in months) & 39.97 & 14.24 \\
\hline Girl & 0.49 & 0.50 \\
\hline The child is oldest among siblings & 0.56 & 0.50 \\
\hline Mother's age & 34.25 & 7.00 \\
\hline Father's age & 36.47 & 9.44 \\
\hline Mother's years of education (>9 compulsory years) & 5.04 & 2.36 \\
\hline Father's years of education (>9 compulsory years) & 4.75 & 2.44 \\
\hline Parents are born outside the Nordic countries & 0.22 & 0.42 \\
\hline Parents and child are born outside the Nordic countries & 0.01 & 0.12 \\
\hline Parents are born outside the EU & 0.15 & 0.36 \\
\hline Mother receives study grant & 0.11 & 0.31 \\
\hline Father receives study grant & 0.03 & 0.16 \\
\hline Information about the mother is missing & 0.00 & 0.06 \\
\hline Information about the father is missing & 0.02 & 0.15 \\
\hline \multicolumn{3}{|l|}{ B. Preschool information (at preschool level): } \\
\hline Number of children in the preschool & 60.84 & 35.24 \\
\hline Average number of children in each section & 21.74 & 12.77 \\
\hline Median age within the preschool sections & 45.54 & 9.26 \\
\hline Standard deviation of age within the preschool sections & 11.38 & 3.76 \\
\hline
\end{tabular}

\subsection{Absence due to illness among preschool children}

Before we describe the health intervention, we illustrate the link between our two outcome measures: the use of temporary parental benefits for care for an ill child (TPB) and reported absence due to illness from the preschools. We also show how illnessrelated absence varies across age groups and across preschools.

\subsubsection{Comparing the two measures of child health}

As we discussed above, parents' use of TPB underestimates the extent to which children are absent from preschool due to illness as parents do not always use these benefits. Since we also have access to absence data from the preschools, we can get an accurate estimate of the extent to which TPB underestimates children's illness-related absence. Table 2 shows the relationship between reported absence due to illness at the preschool 
and parents' use of TPB. We present the figures separately by month and type of preschool section (i.e. age homogenous groups [ages 1-3 and 3-5] and mixed age groups [ages $1-5]) .^{13}$

The table shows that the use of TPB only captures about one third of children's actual absence due to illness. ${ }^{14}$ It also shows that there is large seasonal variation in the absence level: children are most absent due to illness in February, followed by March, and least absent in May. ${ }^{15}$ However, there are no large monthly differences in the level of underreporting. The absence level also varies with the age composition among the children: preschool sections with younger children have a higher level of absence due to illness than sections with mixed ages and sections with older children (we will return to this in the next sub-section). But there are, again, no large differences in the level of underreporting.

Table 2: Average number of days absent due to illness according to use of TPB and as reported by the preschool 2008-2012, by month and age composition within the group

\begin{tabular}{|c|c|c|c|c|c|c|c|c|c|}
\hline \multirow[b]{2}{*}{ Month } & \multicolumn{3}{|c|}{$\begin{array}{c}\text { Age homogenous groups, } \\
\text { ages } 1-3\end{array}$} & \multicolumn{3}{|c|}{$\begin{array}{l}\text { Mixed age groups, } \\
\text { ages } 1-5\end{array}$} & \multicolumn{3}{|c|}{$\begin{array}{c}\text { Age homogenous groups, } \\
\text { ages } 3-5\end{array}$} \\
\hline & $\begin{array}{l}\text { (1) } \\
\text { TPB }\end{array}$ & $\begin{array}{c}(2) \\
\text { Actual }\end{array}$ & $\begin{array}{c}\text { (3) } \\
\text { TPBI } \\
\text { Actual }\end{array}$ & $\begin{array}{l}\text { (4) } \\
\text { TPB }\end{array}$ & $\begin{array}{l}(5) \\
\text { Actual }\end{array}$ & $\begin{array}{c}\text { (6) } \\
\text { TPBI } \\
\text { Actual } \\
\end{array}$ & $\begin{array}{l}\text { (7) } \\
\text { TPB }\end{array}$ & $\begin{array}{c}(8) \\
\text { Actual }\end{array}$ & $\begin{array}{c}\text { (9) } \\
\text { TPBI } \\
\text { Actual } \\
\end{array}$ \\
\hline Jan. & 0.710 & 2.125 & 0.334 & 0.533 & 1.475 & 0.361 & 0.422 & 1.274 & 0.332 \\
\hline Feb. & 0.967 & 3.160 & 0.306 & 0.724 & 2.172 & 0.333 & 0.563 & 1.914 & 0.294 \\
\hline March & 0.904 & 2.862 & 0.316 & 0.630 & 1.894 & 0.333 & 0.536 & 1.770 & 0.303 \\
\hline April & 0.605 & 1.897 & 0.319 & 0.427 & 1.250 & 0.342 & 0.341 & 1.065 & 0.320 \\
\hline May & 0.523 & 1.564 & 0.334 & 0.355 & 0.958 & 0.370 & 0.280 & 0.839 & 0.333 \\
\hline Sept. & 0.555 & 1.819 & 0.305 & 0.412 & 1.222 & 0.337 & 0.331 & 1.081 & 0.306 \\
\hline Oct. & 0.699 & 2.236 & 0.313 & 0.481 & 1.390 & 0.346 & 0.380 & 1.208 & 0.315 \\
\hline Nov. & 0.714 & 2.449 & 0.291 & 0.531 & 1.622 & 0.327 & 0.417 & 1.456 & 0.286 \\
\hline Dec. & 0.587 & 2.094 & 0.280 & 0.455 & 1.412 & 0.322 & 0.343 & 1.217 & 0.282 \\
\hline Total & 0.696 & 2.250 & 0.309 & 0.507 & 1.494 & 0.339 & 0.402 & 1.318 & 0.305 \\
\hline
\end{tabular}

Note: Absence due to illness is the total number of days children are reported ill per preschool section and month, divided by the number of children enrolled in the section that particular month. Absence with TPB is the sum of days with TPB per section and month, divided by the number of children enrolled in the section that particular month.

\footnotetext{
${ }^{13}$ This is the division used in the absence data from the preschools.

${ }^{14}$ This finding is in line with the results of Hedin et al. (2009). For a sample of 835 Swedish families, they find that parents claim social insurance for about one third of the days children are absent from childcare due to symptoms of infections.

${ }^{15}$ The months June, July and August are not included in the absence data from the preschools since many preschools close during parts of the summer.
} 
In Figure 2 we take a closer look at the seasonal variation in the data. We can see that children's illness-related absence follows a similar seasonal pattern each year, both if measured by accounts from the preschools and by the parents' use of TPB.

From the numbers presented in this section we draw the conclusion that the extent to which parents rely on TPB when their child is ill, does not seem to vary systematically with either season or age group.

Figure 2: Number of days reported ill and number of days parents used TPB per month

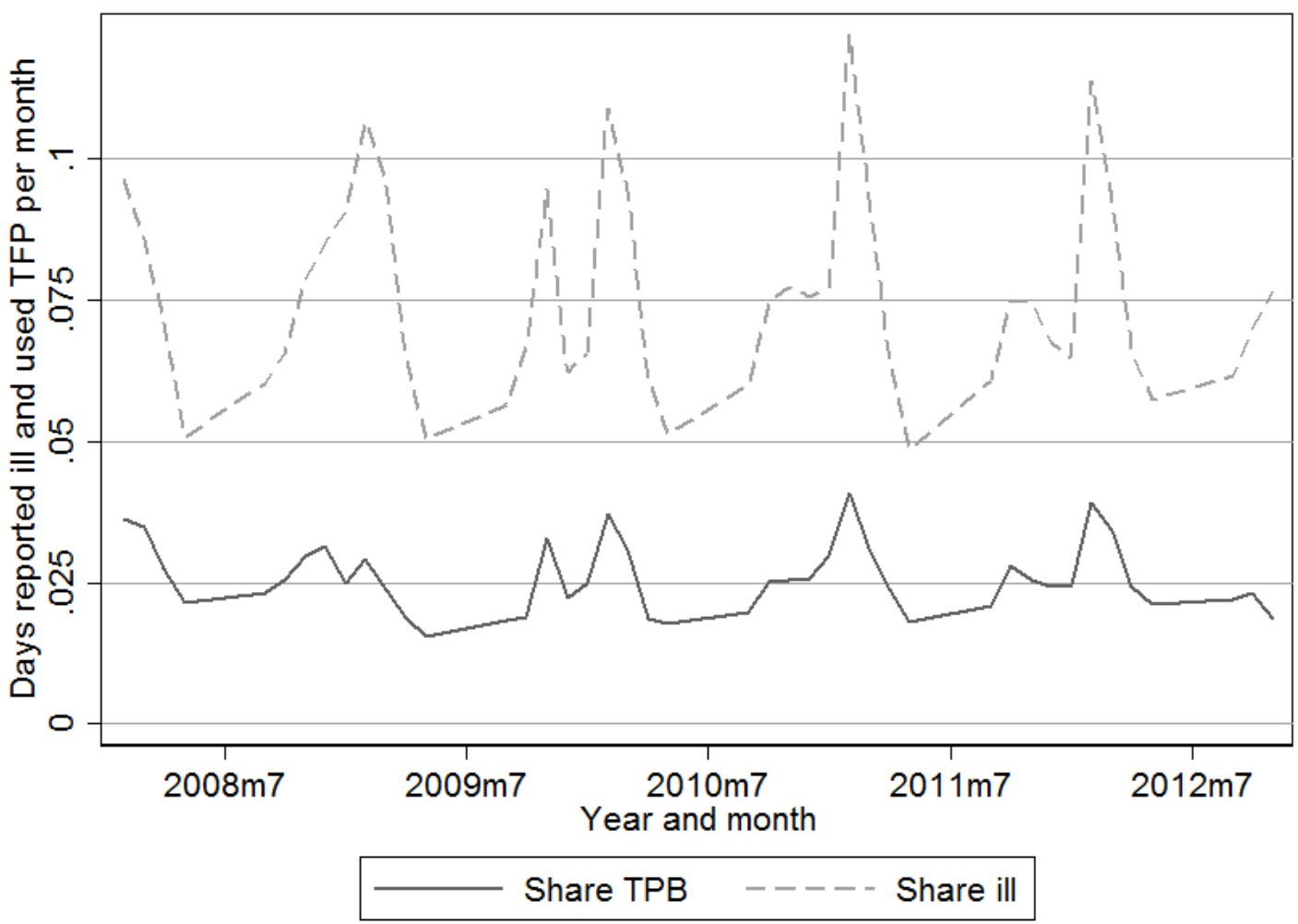

\subsubsection{Differences in illness-related absence across age groups}

Earlier studies have documented an age gradient in infectious illness among preschool children (e.g. Wald et al. 1991 and Huskins 2000). Therefore, we begin by looking closer at how absence due to illness varies depending on age. When studying differences across age groups (throughout the paper), we divide the children into "expected preschool grades” following the school year. Hence, the first "preschool grade” starts in August the year the child turns 1 and ends in July the following year, the second grade starts in August the year the child turns 2 and ends in July the year after, and so on. Table 3 presents the number and shares of children in each expected grade, along with the average age. Most children do not start preschool until they are (at least) one and a 
half years old, hence the share of children in grade 1 is smaller than the share in grades 2-5 (11-12 percent compared to 19-26 percent).

Table 3: Number of children and mean age in different preschool grades in our sample, year 2005 and 2012

\begin{tabular}{lcccccc}
\hline & \multicolumn{3}{c}{2005} & \multicolumn{3}{c}{2012} \\
\hline $\begin{array}{l}\text { Expected preschool } \\
\text { grade }\end{array}$ & Freq. & Share & $\begin{array}{c}\text { Mean age in } \\
\text { months }\end{array}$ & Freq. & Share & $\begin{array}{c}\text { Mean age in } \\
\text { months }\end{array}$ \\
1 & 2,612 & 0.12 & 17.92 & 3,008 & 0.11 & 17.67 \\
2 & 5,264 & 0.24 & 27.62 & 5,921 & 0.22 & 27.73 \\
3 & 5,276 & 0.24 & 39.61 & 5,864 & 0.21 & 39.47 \\
4 & 4,785 & 0.22 & 51.43 & 5,578 & 0.20 & 51.63 \\
5 & 4,168 & 0.19 & 63.41 & 7,120 & 0.26 & 69.38 \\
Total & 22,105 & & 41.24 & 27,491 & & 44.77 \\
\hline
\end{tabular}

Note: The sample consists of all children enrolled in preschool in Gothenburg, Öckerö, Lerum and Kungälv in October 2005 and 2012.

Table 4 shows absence due to illness for each expected grade, as measured by parents’ use of TPB. There are large differences between grades: Children in the first grade are more than twice as much absent compared to children in grade 4 and 5 . Figure 3 reveals that this pattern is very persistent over the years. ${ }^{16}$ The absence level for the youngest age group must be regarded as high: 0.73 days with TPB should, using the calculated relationship in Table 2 (col. 3), correspond to 2.4 days in actual illness-related absence per month, or an absence rate of around 12 percent (2.4/19.5 days $\left.{ }^{17}\right)$. Table 4 also shows that there is large variation within age groups: while first grade children in the $10^{\text {th }}$ percentile of the distribution of children with respect to TPB-days have no days with TPB, children in the $90^{\text {th }}$ percentile have 3 days with TPB per month, which should (again using the relationship in Table 2, col. 3) correspond to 10 days of actual absence per month, or an absence rate of around 50 percent.

\footnotetext{
${ }^{16}$ As mentioned above, an age gradient in infectious illness among preschool children has been documented earlier; see e.g. Wald et al. (1991) and Huskins (2000). Note that the age gradient that we observe could be due to a lower rate of infections among older children, but it could also, at least partly, be due to that older children are more often present at preschool despite having an infection.

${ }^{17}$ According to the absence data collected from the preschools, preschools are on average open 19.5 days per month.
} 
Table 4: Summary statistics for temporary parental benefits (TPB) per month and child

\begin{tabular}{lcccc}
\hline $\begin{array}{l}\text { Expected preschool } \\
\text { grade }\end{array}$ & Mean & Standard dev. & $\mathbf{1 0}^{\text {th }}$ percentile & $\mathbf{9 0}^{\text {th }}$ percentile \\
\hline 1 & 0.73 & 1.69 & 0.00 & 3.00 \\
2 & 0.55 & 1.45 & 0.00 & 2.00 \\
3 & 0.40 & 1.24 & 0.00 & 1.00 \\
4 & 0.35 & 1.14 & 0.00 & 1.00 \\
5 & 0.30 & 1.04 & 0.00 & 1.00 \\
\hline Total & 0.45 & 1.31 & 0.00 & 2.00
\end{tabular}

Note: The sample consists of all children enrolled in preschools in Gothenburg, Öckerö, Lerum and Kungälv during 2005-2012.

Figure 3: Average number of days per month with temporary parental benefits (TPB), by expected preschool grade

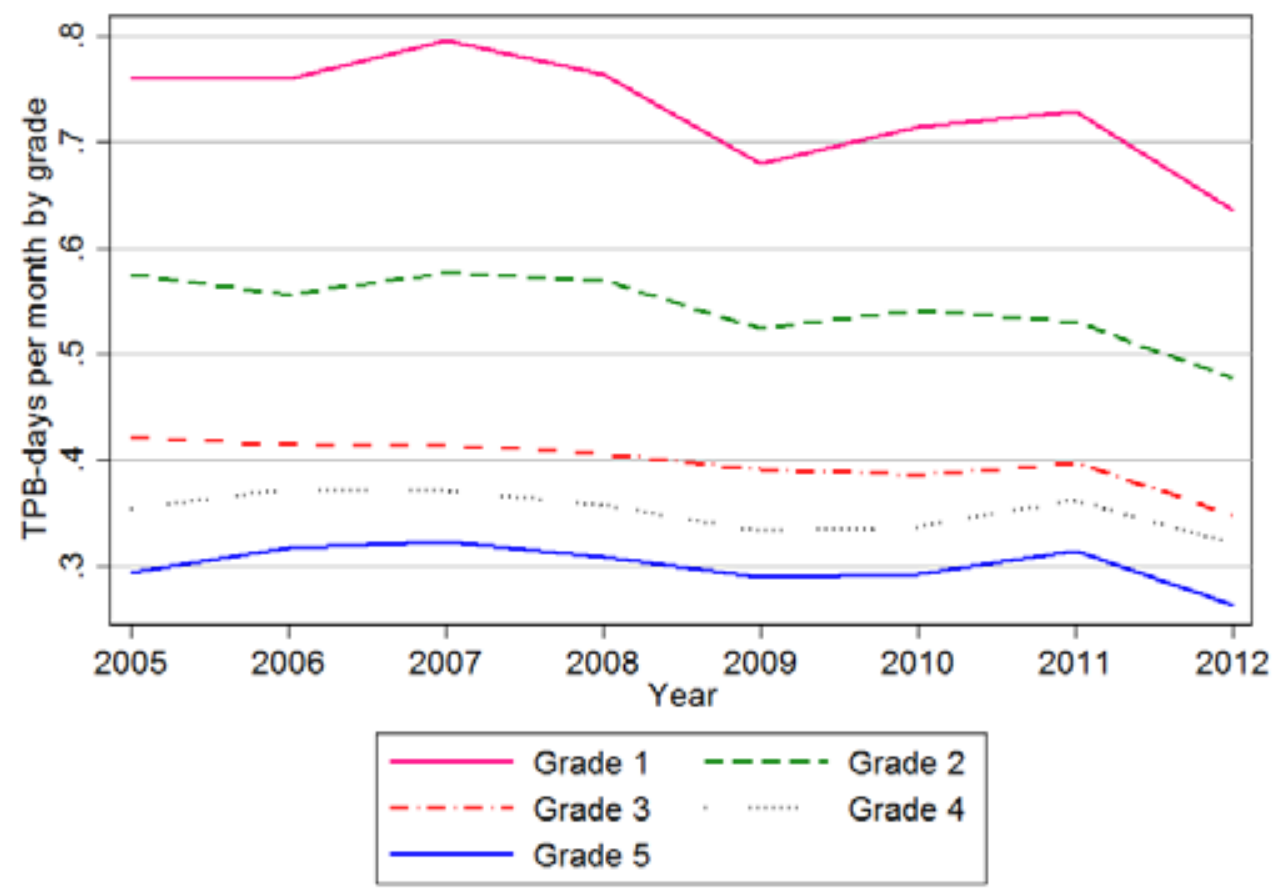

\subsubsection{Differences in illness-related absence across preschools}

The purpose of this paper is to evaluate the effect of a preschool intervention aimed at reducing infectious illness. As a point of departure for the main analyses we begin by asking the following:

i) To what extent does absence due to illness vary between preschools?

ii) How much of the observed differences in illness-related absence can be explained by the selection of children, e.g., by differences in socioeconomic background? 
Figure 4 attempts to answer the first question. It illustrates the variation in absence due to illness across preschools, by showing the number of days with TPB per month for different percentiles of the distribution of preschools with respect to TPB-use. The figure shows that there is considerable variation between preschools: the differences in absence due to illness between preschools at the 90th and 10th percentile of the distribution are $0.5-0.6$ days per month.

Figure 4: Variation in number of days/month with temporary parental benefits (TPB) across preschools

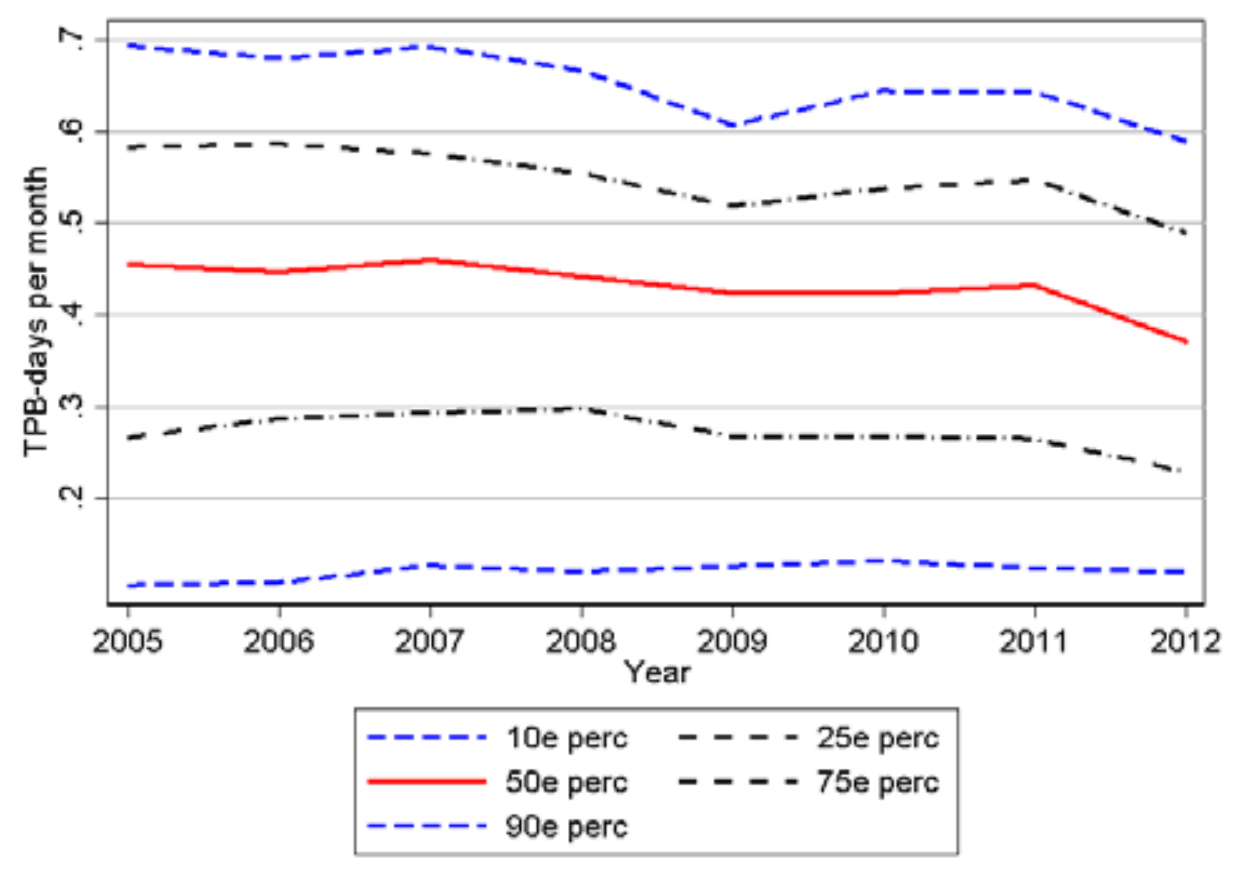

Note: The figures are weighted by the number of children per preschool and collapsed by year.

In Figure 5 we try to answer the second question by illustrating to what extent this variation can be explained by observable differences in child characteristics. If most of the differences between preschools are due to that children with good/poor health tend to be concentrated to certain preschools, there is less reason to believe that preschool quality, in terms of hygiene practices, is an important determinant of child illness. ${ }^{18}$

We first show the variation in the average number of days with TPB per month across preschools, only adjusting for seasonal variation (yearly observations). This plot (left) is comparable to Figure 4 with a difference between preschools at the $90^{\text {th }}$ and $10^{\text {th }}$ percentile of the distribution of preschools with respect to TPB-days of around half a

\footnotetext{
${ }^{18}$ For details on how the analysis in Figure 5 is conducted, see Appendix 1.
} 
day. The second plot (right) shows the remaining variation after controlling for the available background characteristics (see Panel A in Table 1). Differences in these characteristics account for about 40 percent of the variation across preschools. ${ }^{19}$ Hence, children whose parents frequently use TPB tend, to a fairly large extent, to be selected into the same preschools. This could, at least partly, be explained by differences in underlying health, but also by the fact that parents' entitlement to these benefits differ across preschools. In areas where fewer people have jobs, parents are likely to use TPB to a lesser extent. However, there is still much unexplained variation (i.e., 60 percent) in illness-related absence, indicating that preschool quality and organization may play an important role for the extent to which children are ill.

Figure 5: Variation in the average number of TPB days/month across preschools, after controlling for differences in individual characteristics

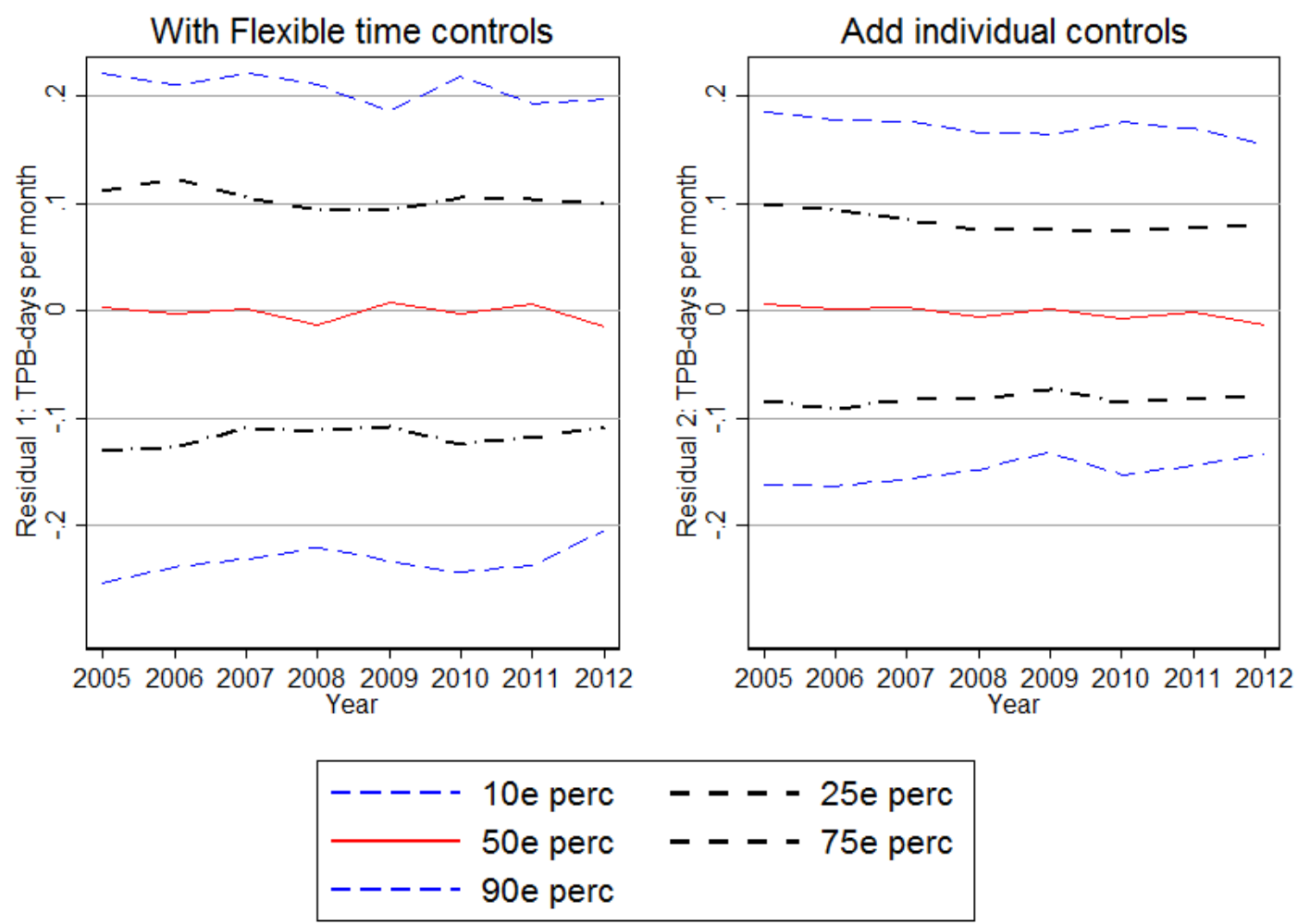

Note: The numbers are weighted by the number of children per preschool and collapsed by year.

19 This figure stems from comparing the 90/10 percentile levels before and after controlling for individual background variables. 


\section{The health intervention}

The health intervention HYFS ${ }^{20}$ was introduced in Gothenburg municipality in 2006. Its specific aim was to reduce the number of infections among preschool children through improved hygiene practices and education of the staff. The program included several components, and we evaluate its overall impact.

The intervention began with a startup meeting with the preschool director. The preschool then appointed one of its staff to be responsible for hygiene and answered a survey involving detailed questions on existing hygiene practices (e.g. regarding hand hygiene, toilet/diaper routines, food handing and cleaning/surface disinfection). ${ }^{21}$ Following this, a nurse, specialized in hygiene, visited the preschool for further examination of the routines and this meeting was followed by a 2-hour lecture for the staff on how to prevent contagious illness among children. In some cases there was a follow-up meeting a few months later. The main area emphasized in the project was the importance of hand hygiene, and thereafter (in order of importance) diaper routines, food handling, and cleaning of toys. The preschools were also encouraged to use guidelines regarding recommended length of absence for various types of infections in order to reduce their spread (e.g. children should preferably be symptom-free for 48 hours before returning to preschool in the case of stomach flu, and for 24 hours in case of fever). As a part of the program, preschools have also been able to contact a nurse for advice, e.g. during outbreaks of infections. ${ }^{22}$

The intervention was rolled out district by district from the end of 2006 until the end of 2012. In 2007 only six of Gothenburg's 21 districts participated; in 2012 the program covered all districts in the city and virtually all public (and a few private) preschools. Table 5 shows the share of treated children each year. ${ }^{23}$

\footnotetext{
20 "Hygiensjuksköterska i förskolan” (Nurse specialized in hygiene for preschools); see Smittskydd Västra Götaland (2014) for more details on the intervention.

${ }^{21}$ See Section 6.3 for more information on the survey.

22 Throughout the project, educational material as well as information and guidelines for the preschool staff, parents and healthcare professionals have been available on the project's website. Preschools (and others) have also been able to learn about the project through newsletters.

${ }^{23}$ From the fall of 2010, the intervention was also spread to the neighboring municipalities in our data. However, since we lack information on when each specific preschool was treated for these municipalities, we censor the data when the intervention began in each of these municipalities.
} 
Table 5: Number of children enrolled in preschool and share of children each year in our sample

\begin{tabular}{lrr}
\hline Year & Number of children enrolled in preschool & Accumulated share of treated children \\
\hline 2005 & 22,105 & 0.00 \\
2006 & 24,345 & 0.00 \\
2007 & 25,909 & 0.14 \\
2008 & 27,409 & 0.33 \\
2009 & 29,050 & 0.46 \\
2010 & 27,741 & 0.61 \\
2011 & 29,572 & 0.65 \\
2012 & 27,491 & 0.71 \\
\hline Total & 213,622 & 0.39 \\
\hline
\end{tabular}

Note: The table shows enrollment in October each year. The sample consists of all children enrolled in preschool in Gothenburg, Öckerö, Lerum and Kungälv. A preschool is considered treated after the start-up meeting has taken place; in a few cases where this date is missing we consider the inspection date to be the start of treatment.

Neither the order in which districts were treated, nor the order among preschools within districts, was randomized but, according to the head of the program, arbitrarily chosen by the nurse responsible for examining the hygiene practices and educating the staff. Table 6 examines whether there appears to be any systematic selection of preschools based on previous levels of illness-related absence. For instance, did preschools with a relatively high (or low) absence level tend to be included at an earlier point in time? The table presents the average number of days that parents used TPB per month the previous year, among newly treated preschools and preschools that were still untreated at the end of the year. The preschools that received the intervention during 2007 and 2009 had very similar levels of absence, in the preceding year, to preschools that were not yet included, but there are significant differences for both 2008 and 2010. The preschools that received the intervention in 2008 appear to have had healthier children than those who remained untreated, while we see the reverse pattern for 2010. Hence, there does not seem to be any systematic selection of preschools based on previous absence levels. Nevertheless, this comparison suggests that it may still be important to account for previous levels of illness-related absence in the analysis. We discuss how we do this in the following section. 
Table 6: Average number of days per month with TPB during the previous year, among newly treated and still untreated preschools

\begin{tabular}{|c|c|c|c|}
\hline & Number of obs. & Mean & t-statistic \\
\hline Received the intervention during 2007 & 81,855 & 0.47 & -0.29 \\
\hline Still untreated & 205,249 & 0.47 & \\
\hline Received the intervention during 2008 & 29,252 & 0.45 & 3.83 \\
\hline Still untreated & 191,819 & 0.48 & \\
\hline Received the intervention during 2009 & 53,784 & 0.47 & -0.97 \\
\hline Still untreated & 152,730 & 0.46 & \\
\hline Received the intervention during 2010 & 30,597 & 0.48 & -7.57 \\
\hline Still untreated & 133,822 & 0.42 & \\
\hline Received the intervention during 2011 & 945 & 0.50 & -1.93 \\
\hline Still untreated & 131,757 & 0.41 & \\
\hline
\end{tabular}

\section{$5 \quad$ Estimating the effect of the health intervention}

The health intervention may have improved hygiene practices in several dimensions, which can affect children's health through various channels: First, improved hygiene may reduce the risk of falling ill, i.e. lower the incidence of illness. Second, it may reduce the duration of a given illness spell. Third, since many infections are contagious, reducing one individual's risk of falling ill also diminishes the risk that he or she will infect others. To capture all three channels we focus on the number of days children are absent from preschool due to illness.

Since we observe absence due to illness, rather than illness per se, we also need to recognize the possibility that the health intervention could have affected parents' judgment of whether a child was well enough to attend preschool. As a part of the intervention, preschools were given guidelines regarding recommended length of absence for different types of infections. These guidelines may have induced parents to keep their child home longer, or more frequently, than they otherwise would. Preschool staff may also have acted on these guidelines, e.g. by more often sending home children that are ill. Hence, there is a channel through which the intervention potentially also 
could have increased illness-related absence. The estimated effect on illness-related absence is therefore likely to be an underestimation of the effect on child illness.

As we discussed in the previous section, the order in which preschools were treated was not randomized. To account for the non-random implementation of the intervention across preschools, we employ a difference-in-differences strategy. Hence, we compare the change in illness-related absence before and after treatment among children in treated preschools with the change in illness-related absence during the same time period among children in not yet treated preschools. More specifically, we estimate the following regression model:

Days absent $_{i p m}=\alpha_{0}+\alpha_{1}$ Intervention $_{p m}+\alpha_{2} X_{i p m}+\alpha_{3} Z_{p m}+\theta_{m}+\delta_{p}+e_{i p m}$

where Days absent $t_{i p m}$ is the number of days absent due to illness for child $i$, who

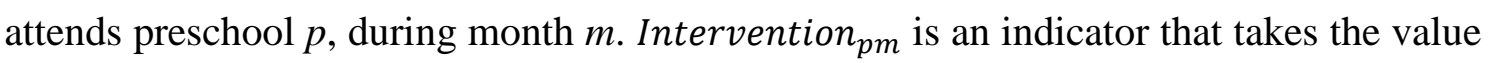
one once the preschool has taken part of the intervention and zero otherwise. $X_{i p m}$ is a vector of individual characteristics ${ }^{24}$ and $Z_{p m}$ is a vector of preschool characteristics (the individual and preschool characteristics are listed below). $\theta_{m}$ and $\delta_{p}$ represent month-by-year and preschool fixed effects, respectively.

Using a difference-in-differences design we are able to control for all differences between preschools that are constant over time; hence, we can account for that preschools differed in the level of illness-related absence before the intervention took place. However, we need to assume that trends in illness-related absence would not differ between treated and untreated preschools in the absence of the intervention. In order to test this assumption we estimate a model that additionally incorporates preschool specific linear trends (using yearly data). We also perform placebo tests by estimating the same model but where the intervention is (artificially) defined to have taken place one, two, three, or four years before its actual implementation (see Section $6.2)$.

As we outlined in the previous section, the health intervention consisted of several parts: a start-up meeting with the preschool director, an inspection of existing hygiene

\footnotetext{
24 The following individual characteristics are updated monthly: age, expected preschool grade and presence of siblings. The rest are measured at the time the child enrolled in preschool, with the exception of parents' student status which is measured yearly.
} 
practices and, thereafter, a lecture for the staff. We choose to view the date of the startup meeting as the start of the intervention. However, this is not an obvious choice, as the start-up meeting usually took place a few months before the inspection and the lecture for the staff (on average 4 months before; see Table A1 in appendix), and we believe that the latter two components have the greatest potential of influencing the hygiene practices at the preschool. For this reason, we also estimate a model that tries to separate the effect of the hygiene inspection and training of the staff from the effect of the initial start-up meeting; see Section 6.4.

Important to point out is that we do not have information on whether, and to what extent, preschools in fact improved their hygiene practices due to the intervention. Hence, strictly speaking, we estimate the effect of the intervention, rather than the effect of improved hygiene practices, on children's absence due to illness.

The individual background controls in the model include the child's age in months, sex, indicators for the presence of older/younger siblings, indicators for foreign background (if the parents are born outside the Nordic countries, if both the parents and the child are born outside the Nordic countries, or if the parents are born outside the EU), indicators of whether the parents are students (i.e., have received student grants during the current year), and the mother's and father's age and years of education. ${ }^{25} 26$

The vector of preschool characteristics includes the number of children enrolled in the child's preschool a particular month, and the average number of children in each section of the preschool. ${ }^{27}$ Finally, we control for the age composition among the children in the preschool sections. To do this, we include variables measuring the average median age and standard deviation of the sections in the child's preschool.

\section{$6 \quad$ Results}

This section presents the results from the empirical analysis. We begin by discussing the overall effect of the intervention (Section 6.1), followed by the results from a number of placebo tests (Section 6.2). Thereafter we examine whether there are heterogeneous impacts with respect to either child or preschool characteristics (Section 6.3), and in the

\footnotetext{
${ }^{25}$ The parent's age and years of education are controlled for using third order polynomials.

${ }^{26}$ For each variable we also include an indicator of whether the information is missing or not. If information is missing that variable is given the value zero. This way we do not exclude any child from the analyses due to missing information on one or more of the background variables.

${ }^{27}$ These two variables are also controlled for using third order polynomials.
} 
subsequent section we take a closer look at the underlying patterns behind our overall findings (Section 6.4).

\subsection{Estimated overall effect of the health intervention}

Table 7 shows the estimated average effect of the intervention on parents' use of temporary parental benefits. In the first column we only control for month-by-year and preschool fixed effects. In the second we add controls for the child's age in months, the expected preschool grade, sex, and the presence of (younger/older) siblings. In the third column we additionally include the full set of preschool characteristics, and in the fourth we include the full set of parental background controls. Finally, in the last column we also incorporate preschool-specific linear trends. It is indeed possible that adding preschool-specific trends will control for actual responses to the intervention, and not just for pre-intervention trends, and thereby lead to biased estimates (see Wolfers 2006). For this reason, we consider column 4 our preferred specification.

The results suggest that, on average, the health intervention had no effect on children's absence due to illness. The estimated effect is statistically insignificant in all specifications and all point estimates are very close to zero: the point estimate in our preferred specification (column 4) implies a reduction of less than 0.005 days with TPB per month, corresponding to less than 0.06 days for a full year. It is also worth pointing out that the results are stable across the different specifications, and do not change if the model incorporates preschool specific linear trends (column 5). ${ }^{28}$

In Section 3.2.1 we showed that the use of TPB only captures about one third of children's actual absence due to illness. Since it is actual absence due to illness that is our outcome of interest, relying on TPB-data means that we measure the dependent variable with error, which may lead to bias in our estimates. Specifically, we are concerned that if the intervention affects illness-related absence, TPB would only capture part of this change which would bias our estimate towards zero. To examine whether the reliance on TPB-data to measure illness-related absence distorts our findings, we estimate the same model using reported absence due to illness from the preschools as the outcome, for the sample of preschools where this information is

\footnotetext{
${ }^{28}$ In the last column the estimate does change sign but is still close to zero and statistically significant.
} 
available. This sample includes almost all treated preschools between 2007 and 2012, and altogether around 40 percent of the children. ${ }^{29}$

Table 7: Estimated average effect of the intervention on parents' use of temporary parental benefits (TPB)

\begin{tabular}{|c|c|c|c|c|c|}
\hline & (1) & (2) & (3) & (4) & (5) \\
\hline Intervention & $\begin{array}{c}-0.00858 \\
(0.00693)\end{array}$ & $\begin{array}{c}-0.00494 \\
(0.00646)\end{array}$ & $\begin{array}{c}-0.00368 \\
(0.00650)\end{array}$ & $\begin{array}{c}-0.00477 \\
(0.00629)\end{array}$ & $\begin{array}{c}0.00383 \\
(0.00754)\end{array}$ \\
\hline Observations & $2,587,860$ & $2,587,860$ & $2,587,860$ & $2,587,860$ & $2,587,860$ \\
\hline R-squared & 0.034 & 0.052 & 0.052 & 0.059 & 0.060 \\
\hline Mean of dep. variable ${ }^{1}$ & 0.441 & 0.441 & 0.441 & 0.441 & 0.441 \\
\hline Relative effect ${ }^{2}$ & -0.019 & -0.011 & -0.008 & -0.011 & 0.009 \\
\hline \multicolumn{6}{|l|}{ Controls for: } \\
\hline Child characteristics $^{3}$ & no & yes & yes & yes & yes \\
\hline Preschool characteristics ${ }^{4}$ & no & no & yes & yes & yes \\
\hline Parental characteristics ${ }^{5}$ & no & no & no & yes & yes \\
\hline Preschool-spec. trends & no & no & no & no & yes \\
\hline
\end{tabular}

Note: All regressions control for month-by-year and preschool fixed effects. ${ }^{1}$ The mean of the dep. variable is calculated among untreated observations only. ${ }^{2}$ The relative effect is obtained by relating the estimate to the mean of the dependent variable. ${ }^{3}$ The child characteristics include exact age (in months), expected preschool grade, sex, and presence of older/younger siblings. ${ }^{4}$ The preschool controls include, number of children at the preschool, average number of children in each section, and age composition among the children (see Table 1 for details). ${ }^{5}$ The parental characteristics include indicators for foreign background, each parent's age (3rd order polynomial), each parent's years of education (3rd order polynomial), indicators for whether each of the parents is a student, and controls for missing values for any of the variables. Robust standard errors, clustered on preschools, in parentheses. $* / * * / * * *$ denotes significance on the 10/5/1 percent level.

The results from this exercise are shown in Table 8 (for our preferred model specification). The first column shows the estimated effect of the intervention on parents' use of TPB for the sample of preschools where both TPB-data and actual absence data are available. The result for this sample is very similar to the result for the full sample (shown in Table 7): the estimated effect is statistically insignificant and the magnitude of the point estimate is close to zero. The second column shows that the estimated effect is statistically insignificant also if we use actual absence due to illness as the outcome. However, the point estimate is larger in size, corresponding to an increase of 0.03 days per month. The larger estimate for reported illness-related absence suggests that relying on TPB-data to estimate the effect on illness-related absence bias the estimate towards zero. However, the magnitude of the overall effect is still small in absolute terms.

In the third column we take into account the number of days the children were scheduled to attend preschool, which is reported for the same sample of preschools, and instead use the share of days absent due to illness as the outcome. The estimated effect

\footnotetext{
${ }^{29}$ Note, however, that we do not have data for a pre-period for the earliest implementers, as the intervention was rolled out from the end of 2006. Hence, the preschools that first implemented the intervention do not contribute to the identification of the treatment effect in this analysis.
} 
is statistically significant at the 10-percent level in this specification, suggesting that the intervention increased absence due to illness by 0.26 percentage points or 2.6 percent (0.00262/0.1014). In sum, we find no evidence that the health intervention reduced illness-related absence. If anything, absence due to illness seems to have increased slightly. While a positive impact may seem counterintuitive at first, it is not implausible if we recognize that as a part of the intervention preschools were given guidelines regarding recommended length of absence for different types of infections. Such guidelines could have induced parents to keep their children home longer than they otherwise would have done.

Table 8: Comparing the estimated effect across different outcomes

\begin{tabular}{|c|c|c|c|}
\hline & $\begin{array}{c}\text { (1) } \\
\text { No. of TPB-days }\end{array}$ & $\begin{array}{c}(2) \\
\text { No. of days with } \\
\text { illness-related } \\
\text { absence }\end{array}$ & $\begin{array}{l}\text { (3) } \\
\text { Share of days absent due to } \\
\text { illness among scheduled } \\
\text { days }\end{array}$ \\
\hline Intervention & $\begin{array}{l}0.00534 \\
(0.0113)\end{array}$ & $\begin{array}{c}0.0300 \\
(0.0211)\end{array}$ & $\begin{array}{l}0.00262^{\star} \\
(0.00134)\end{array}$ \\
\hline Observations & 716,371 & 716,371 & 716,371 \\
\hline R-squared & 0.535 & 0.442 & 0.469 \\
\hline Mean of dep.variable ${ }^{1}$ & 0.4947 & 1.5459 & 0.1014 \\
\hline Relative effect ${ }^{2}$ & 0.0108 & 0.0194 & 0.0258 \\
\hline \multicolumn{4}{|l|}{ Controls for: } \\
\hline Child characteristics $^{3}$ & yes & yes & yes \\
\hline Preschool characteristics ${ }^{4}$ & yes & yes & yes \\
\hline Parental characteristics ${ }^{5}$ & yes & yes & yes \\
\hline Preschool-spec. trends & no & no & no \\
\hline \multicolumn{4}{|c|}{$\begin{array}{l}\text { Note: The regressions are estimated at the preschool level with each preschool weighted by the number of children } \\
\text { enrolled. All regressions control for month-by-year and preschool fixed effects. }{ }^{1} \text { The mean of the dep. variable is } \\
\text { calculated among untreated observations only. }{ }^{2} \text { The relative effect is obtained by relating the estimate to the mean of } \\
\text { the dependent variable. }{ }^{3} \text { The child characteristics include exact age (in months), expected preschool grade, sex, and } \\
\text { presence of older/younger siblings. }{ }^{4} \text { The preschool controls include number of children at the preschool, average } \\
\text { number of children in each section, and age composition among the children (see Table } 1 \text { for details). }{ }^{5} \text { The parental } \\
\text { characteristics include indicators for foreign background, each parent's age (3rd order polynomial), each parent's } \\
\text { years of education (3rd order polynomial), indicators for whether each of the parents is a student, and controls for } \\
\text { missing values for any of the variables. Robust standard errors, clustered on preschools, in parentheses. }{ }^{*} / * * / * * * \\
\text { denotes significance on the } 10 / 5 / 1 \text { percent level. }\end{array}$} \\
\hline
\end{tabular}

\subsection{Placebo tests}

Our identification strategy relies on the assumption that trends in illness-related absence would not differ between treated and untreated preschools in the absence of the intervention. To assess the credibility of this assumption, we investigate whether there are differences in trends for preschools that were treated at different points in time already during the pre-treatment period. To do this, we perform placebo-tests: We estimate the same model as in Table 7 (col. 4), but (artificially) set the start date of the intervention to 12, 24, 36 and 48 months before the actual start-up meeting. In order to 
make sure that the placebo estimates do not capture the effect of the actual intervention, all observations after the actual start date are dropped in these analyses. Since we only have data on reported absence from the preschools for a limited time period before the intervention, this type of placebo analysis is only possible to conduct using parents' use of TPB as the measure of illness-related absence.

The results from these tests are shown in Table 9. All placebo estimates are very small in size and none are statistically significant, which supports the validity of the empirical strategy. It is important to point out, however, that since our data only go back to 2005, and the intervention was rolled out from the end of 2006 and onwards, the placebo estimates are identified from a limited set of late implementers as we (artificially) move the start date back in time. The first placebo estimate (-12 months) is however identified from almost the full sample of treated preschools. ${ }^{30}$

Table 9: Placebo-estimates on parents use of temporary parental benefits (TPB)

\begin{tabular}{|c|c|c|c|c|}
\hline & (1) & (2) & (3) & (4) \\
\hline Placebo -12 months & $\begin{array}{c}-0.00884 \\
(0.00682)\end{array}$ & & & \\
\hline Placebo -24 months & & $\begin{array}{l}0.000678 \\
(0.00778)\end{array}$ & & \\
\hline Placebo -36 months & & & $\begin{array}{c}0.00225 \\
(0.00929)\end{array}$ & \\
\hline Placebo -48 months & & & & $\begin{array}{c}0.0166 \\
(0.0149)\end{array}$ \\
\hline Observations & $2,587,860$ & $2,587,860$ & $2,587,860$ & $2,587,860$ \\
\hline R-squared & 0.059 & 0.059 & 0.059 & 0.059 \\
\hline \multicolumn{5}{|l|}{ Controls for: } \\
\hline Child characteristics $^{1}$ & yes & yes & yes & yes \\
\hline Preschool characteristics ${ }^{2}$ & yes & yes & yes & yes \\
\hline Parental characteristics ${ }^{3}$ & yes & yes & yes & yes \\
\hline Preschool-spec. trends & no & no & no & no \\
\hline \multicolumn{5}{|c|}{$\begin{array}{l}\text { Notes: Treatment is defined to take place } 12,24,36 \text { or } 48 \text { months before the actual start-up meeting. All regressions } \\
\text { control for month-by-year and preschool fixed effects. }{ }^{1} \text { The child characteristics include exact age (in months), } \\
\text { expected preschool grade, sex, and presence of older/younger siblings. }{ }^{2} \text { The preschool controls include number of } \\
\text { children at the preschool, average number of children in each section, and age composition among the children (see } \\
\text { Table } 1 \text { for details). }{ }^{3} \text { The parental characteristics include indicators for foreign background, each parent's age (3rd } \\
\text { order polynomial), each parent's years of education (3rd order polynomial), indicators for whether each of the parents } \\
\text { is a student, and controls for missing values for any of the variables. Robust standard errors, clustered on preschools, } \\
\text { in parentheses. } * / * * * * * \text { denotes significance on the } 10 / 5 / 1 \text { percent level. }\end{array}$} \\
\hline
\end{tabular}

\subsection{Heterogeneous effects}

Our results do not indicate that the hygiene intervention reduced absence due to illness on average. However, it is still possible that the package of measures to improve hygiene and reduce the spread of infections reduced illness-related absence among

\footnotetext{
${ }^{30}$ Only 4 preschools that implemented the intervention in 2006 are excluded in the first column.
} 
specific groups of children, or certain types of preschools. Below, we examine whether the effect of the intervention varies with either child or preschool characteristics.

As we saw in Section 3.2, there are large differences in illness-related absence depending on child age: the youngest preschool children (ages 1-2 years) are much more often absent due to illness than the older age groups. This type of intervention may therefore have differential effects depending on the age of the children. Table 10 shows results separately for the five expected preschool grades (using our preferred model specification) using parents' use of TPB as the outcome. The estimated effect is statistically insignificant and small in absolute terms for all expected grades - hence, these results do not suggest important differences in effects across age groups.

Since we have to rely solely on parents' use of TPB for this analysis (as reported illness-related absence is only available at the preschool section level), it is possible that the estimates presented in Table 10 are biased towards zero. However, the comparison in Table 2 indicated that the extent to which parents use TBP when their child is ill does not vary systematically across age groups of preschool children. This means that the bias should be similar in all columns of Table 10, and that a comparison of estimates across age groups is still meaningful.

Table 10: Estimated effect of the intervention on parents' use of TPB for different age groups

\begin{tabular}{|c|c|c|c|c|c|}
\hline & $\begin{array}{l}1) \\
\text { Expected } \\
\text { grade } 1\end{array}$ & $\begin{array}{l}\text { (2) } \\
\text { Expected } \\
\text { grade } 2\end{array}$ & $\begin{array}{l}\text { (3) } \\
\text { Expected } \\
\text { grade } 3\end{array}$ & $\begin{array}{l}(4) \\
\text { Expected } \\
\text { grade } 4\end{array}$ & $\begin{array}{l}\text { (5) } \\
\text { Expected } \\
\text { grade } 5\end{array}$ \\
\hline Intervention & $\begin{array}{l}0.00162 \\
(0.0171)\end{array}$ & $\begin{array}{l}-0.00441 \\
(0.0128)\end{array}$ & $\begin{array}{l}-0.00265 \\
(0.0101)\end{array}$ & $\begin{array}{l}-0.00543 \\
(0.00994)\end{array}$ & $\begin{array}{l}-0.00482 \\
(0.00976)\end{array}$ \\
\hline $\begin{array}{l}\text { Observations } \\
\text { R-squared } \\
\text { Mean of dep. variable }\end{array}$ & $\begin{array}{l}375,999 \\
0.079 \\
0.7274\end{array}$ & $\begin{array}{l}556,769 \\
0.070 \\
0.5422\end{array}$ & $\begin{array}{l}551,636 \\
0.053 \\
0.3957\end{array}$ & $\begin{array}{l}529,254 \\
0.039 \\
0.3483\end{array}$ & $\begin{array}{l}574,202 \\
0.035 \\
0.2924\end{array}$ \\
\hline $\begin{array}{l}\text { Controls for: } \\
\text { Child characteristics }^{2} \\
\text { Preschool characteristics } \\
\text { Parental characteristics } \\
\text { Preschool-spec. trends } \\
\text { Prent }\end{array}$ & $\begin{array}{l}\text { yes } \\
\text { yes } \\
\text { yes } \\
\text { no }\end{array}$ & $\begin{array}{l}\text { yes } \\
\text { yes } \\
\text { yes } \\
\text { no }\end{array}$ & $\begin{array}{l}\text { yes } \\
\text { yes } \\
\text { yes } \\
\text { no }\end{array}$ & $\begin{array}{l}\text { yes } \\
\text { yes } \\
\text { yes } \\
\text { no }\end{array}$ & $\begin{array}{l}\text { yes } \\
\text { yes } \\
\text { yes } \\
\text { no }\end{array}$ \\
\hline $\begin{array}{l}\text { Note: All regressions contro } \\
\text { calculated among untreated } \\
\text { preschool grade, sex, and pre } \\
\text { the preschool, average numb } \\
\text { details). }{ }^{4} \text { The parental char } \\
\text { polynomial), each parent’s ye } \\
\text { student, and controls for mis } \\
\text { parentheses. } * / * * / * * * \text { denote }\end{array}$ & $\begin{array}{l}\text { e of older/ } \\
\text { children ir } \\
\text { stics incl } \\
\text { f educatio } \\
\text { values for } \\
\text { ificance o }\end{array}$ & $\begin{array}{l}\text { r siblings. } \\
\text { section, and } \\
\text { licators for } \\
\text { order polyn }\end{array}$ & $\begin{array}{l}\text { preschool } \\
\text { e compositi } \\
\text { reign back } \\
\text { ial), indicat } \\
\text { Robust stan } \\
\text { vel. }\end{array}$ & $\begin{array}{l}\text { l, each par } \\
\text { ong the chi } \\
\text { whether e } \\
\text { rrors, clust }\end{array}$ & $\begin{array}{l}\text { dep. variab } \\
\text { onths), exp } \\
\text { er of childr } \\
\text { (see Table } \\
\text { age (3rd } \\
\text { f the parent } \\
\text { on preschoo }\end{array}$ \\
\hline
\end{tabular}


In Table 11 we examine whether the effect of the intervention varies by different preschool characteristics that may be important for children's amount of illness-related absence. We examine the importance of group size, age composition among the children, initial hygiene conditions, and level of TPB-use in 2005 (i.e. before the intervention was rolled out).

Frequently meeting a larger group of children should imply a higher risk of being exposed to contagious illnesses. Since younger children are more often ill compared to older children, the age composition among the children may matter as well. Both of these hypotheses are supported by our data: Children in the smallest groups have the lowest level of absence due to illness (see Figure A1), and young children (grade 1 and 2) who attend groups with many other young children are more frequently ill than children of the same age who attend mixed age groups (see Figure A2). One should note, however, that it is possible that these patterns are mainly explained by selection, i.e. that children that differ in characteristics are selected to different types of groups.

In Table 11 we present results separately for children who attend preschool sections with less than 15 children (small groups), and for those who attend sections with at least 15 children (large groups). We also show results separately for children in sections that have a median age below 3 (toddler groups), and those in sections with a median age of 3 or above (mixed/older groups). The results indicate that the effect of the intervention does not differ depending on the age composition among the children (see panel A, col. 3 and 4), but that the group size may play a role (see col. 1 and 2). There is a statistically significant reduction in parents' use of TPB due to the intervention among children in sections with less than 15 children. A potential explanation for such heterogeneous effects could be that it is easier to implement and keep up strict hygiene practices in smaller groups of children. However, the magnitude of the estimated effect is small, corresponding to a decrease in the number of TPB-days of 0.024 days per month, or 0.283 days per year.

Depending on a preschool's existing hygiene practices there may have been different room for improvement. In the beginning of the intervention, the preschools answered a survey with detailed questions on existing practices. The survey, which consisted of 40 questions, covered a number of areas relevant for the spread of infections; e.g. hand hygiene, food handling, cleaning/surface disinfection, toilet and diaper routines, and 
sleeping environment. ${ }^{31}$ We have summarized the answers on the questions relating to hand hygiene (which was the primary area emphasized in the project) to an index (ranging from 4-13, where higher values correspond to better hygiene practices). In panel B of Table 11, we show results from separate regressions for preschools that scored above and below average on this index; see col. 1 and 2. In the last two columns we have instead split the sample according to the preschools level of TPB-use in 2005 (i.e. before the intervention was rolled out). We distinguish preschools with high levels of TPB ( $>75$ th percentile) from the rest of the sample ( $<75$ th percentile). The results do not indicate that there is a differential effect of the intervention with respect to the preschool's initial hygiene practices or previous level of TPB-use.

Our results in the previous section indicated that relying on TPB-data to capture the effect on illness-related absence may bias our estimates towards zero. Unfortunately, using the data on reported absence due to illness in order to assess the magnitude of such a bias turns out to be difficult in this case. For the smaller sample of preschools for which reported absence data is available, the estimates for parents' use of TPB differ from the estimates presented in Table 11 (see Table A2 in the Appendix). Hence, while the estimates in Table 11 can be interpreted as the causal effects on the number of TPBdays, it is uncertain to what extent the estimates also reflect the causal effects on illnessrelated absence.

\footnotetext{
${ }^{31}$ The survey information is available for 31 percent of the treated preschools.
} 
Table 11: Estimated effect of the intervention on parents' use of TPB, by preschool and group characteristics

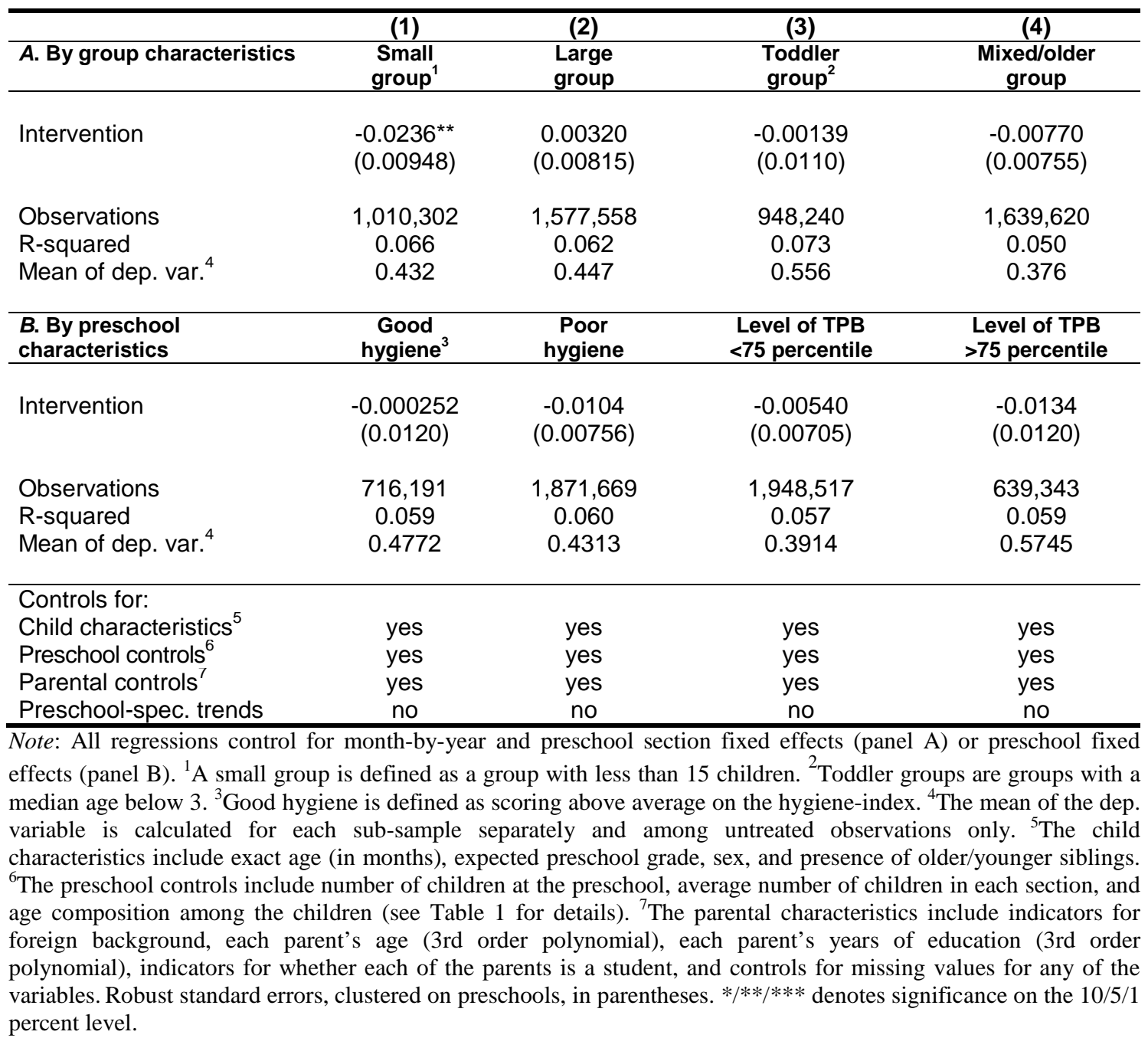

\subsection{Understanding the absence of an effect}

Our results so far indicate that, on average, the health intervention did not reduce absence due to illness among the children. In this section, we use data on the timing of the different parts of the intervention, along with information on what type of illness the children suffered from in order to shed some light on what could explain the absence of an overall effect.

\subsubsection{Effects of different parts of the intervention}

As we discussed earlier, it is not obvious how to define the starting point of the intervention: The two components that are likely to have the greatest potential to influence the hygiene practices at the preschool (i.e. the inspection of hygiene practices and the lecture for the staff) generally took place within a month and a few months after the initial start-up meeting (on average 4 months later; see Table A1 in the appendix). 
Below, we show results from a model in which we try to separate the effect of the hygiene inspection and training of the staff from the effect of the initial start-up meeting. To do this, we add an additional treatment indicator to our original model,

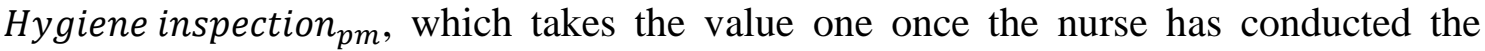
inspection of the preschool's hygiene practices, and zero otherwise. The first treatment indicator, Intervention $_{p m}$, thus captures the effect of the initial start-up meeting, while

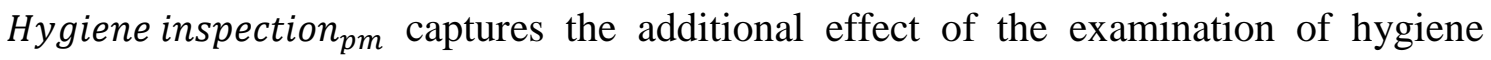
practices along with the lecture for the staff.

Table 12 shows results from this model when parents' use of TPB is used as outcome variable (for the same five specifications as in Table 7). The estimates indicate that the start-up meeting may have resulted in an increase in illness-related absence. This effect is not statistically significant in our preferred specification (col. 4), but it is significant at the five percent level in the model that includes preschool specific linear trends (col. 5). As we discussed before, a likely cause of such a development could be stricter guidelines regarding absence during contagious infections. In the survey which was conducted just before the inspection of hygiene practices, 399 out of 946 preschool sections (42 percent) answered that they had already implemented the recommended guidelines.

The (additional) effect of the inspection and training is strongly significant in all specifications. Hence, given that we account for the initial increase in illness-related absence, the results indicate that the efforts to improve hygiene and reduce the spread of infections decreased absence due to illness at the preschools. This pattern of results indicates that it is possible that, although we find no overall reduction in illness-related absence, children's health still improved as a result of the intervention. The estimate in our preferred specification (col. 4) suggests a decrease in illness-related absence of around 0.02 days per month on average (or 0.24 days per year) if measured by parents' use of TPB, which corresponds to a decrease by 4 percent (-0.0198/0.4407). In Table A3 in appendix we show that the pattern is rather similar if we instead use reported illness-related absence as the outcome (for the smaller sample of preschools for which this information is available). 
Table 12: Estimated effect of different parts of the intervention on parents' use of temporary parental benefits (TPB)

\begin{tabular}{|c|c|c|c|c|c|}
\hline & (1) & (2) & (3) & (4) & (5) \\
\hline Intervention & $\begin{array}{c}0.0139 \\
(0.00849)\end{array}$ & $\begin{array}{c}0.0161^{*} \\
(0.00842)\end{array}$ & $\begin{array}{c}0.0163^{*} \\
(0.00848)\end{array}$ & $\begin{array}{c}0.0103 \\
(0.00821)\end{array}$ & $\begin{array}{c}0.0197^{\star *} \\
(0.00900)\end{array}$ \\
\hline Hygiene inspection & $\begin{array}{c}-0.0294^{\star \star *} \\
(0.00812)\end{array}$ & $\begin{array}{l}-0.0275^{\star \star *} \\
(0.00813)\end{array}$ & $\begin{array}{c}-0.0263^{\star * \star} \\
(0.00812)\end{array}$ & $\begin{array}{l}-0.0198^{\star *} \\
(0.00785)\end{array}$ & $\begin{array}{l}-0.0231^{\star * *} \\
(0.00877)\end{array}$ \\
\hline Observations & $2,587,860$ & $2,587,860$ & $2,587,860$ & $2,587,860$ & $2,587,860$ \\
\hline R-squared & 0.034 & 0.052 & 0.052 & 0.059 & 0.060 \\
\hline Men of dep. variable ${ }^{1}$ & 0.4407 & 0.4407 & 0.4407 & 0.4407 & 0.4407 \\
\hline Relative effect intervention ${ }^{2}$ & 0.0315 & 0.0365 & 0.0370 & 0.0234 & 0.0447 \\
\hline Relative effect inspection ${ }^{2}$ & -0.0667 & -0.0624 & -0.0597 & -0.0449 & -0.0524 \\
\hline \multicolumn{6}{|l|}{ Controls for: } \\
\hline Child characteristics $^{3}$ & no & yes & yes & yes & yes \\
\hline Preschool controls ${ }^{4}$ & no & no & yes & yes & yes \\
\hline Parental controls ${ }^{5}$ & no & no & no & yes & yes \\
\hline Preschool-spec. trends & no & no & no & no & yes \\
\hline
\end{tabular}

Note: All regressions control for month-by-year and preschool fixed effects. ${ }^{1}$ The mean of the dep. variable is calculated among the untreated observations only. ${ }^{2}$ The relative effect is obtained by relating the estimate to the mean of the dependent variable. ${ }^{3}$ The child characteristics include exact age (in months), expected preschool grade, sex, and presence of older/younger siblings. ${ }^{4}$ The preschool controls include number of children at the preschool, average number of children in each section, and age composition among the children (see Table 1 for details). ${ }^{5}$ The parental characteristics include indicators for foreign background, each parent's age (3rd order polynomial), each parent's years of education (3rd order polynomial), indicators for whether each of the parents is a student, and controls for missing values for any of the variables. Robust standard errors, clustered on preschools, in parentheses. */**/*** denotes significance on the 10/5/1 percent level.

We want to emphasis however, that it is not possible to completely separate the effects of the different parts of the intervention; the reduction in illness-related absence that seems to take place from the inspection onwards could be partly caused by the fact that the children were absent more often after the start-up meeting, which could have reduced the spread of infections. Moreover, the identification of the separate effects of the inspection and training relies on the strong assumption that the effect of the start-up meeting is constant over time. ${ }^{32}$ Our conclusion from these results is not that illnessrelated absence among preschool children is not responsive to this type of intervention. Rather, the overall null effect may be the sum of two opposing effects.

\subsubsection{Effects on absence due to different types of infections}

When the preschools recorded illness-related absence they were also asked to register what type of illness the children suffered from: 1) upper respiratory tract infections; 2) diarrhea/vomiting; 3) other infections (e.g. fever only, eye infection, impetigo or

\footnotetext{
${ }^{32}$ An additional caveat regarding this analysis is that we use data for a rather short time period when estimating the effect of the start-up meeting. This may affect the reliability of the estimates in this setting because of a large monthto-month variation in the outcome variable.
} 
chickenpox); or 4) non-contagious illness. ${ }^{33}$ Table 13 shows results from the same model as in Table 12, but now absence due to the different categories of illness is used as the outcome. The results are in line with the pattern found in the previous section, i.e. that the start-up meeting was followed by an increase in illness-related absence, while the inspection and training seem to have contributed to a decrease, at least according to the only statistically significant parameter capturing the effect following the inspection. The estimate for the variable capturing the start-up meeting is positive and very similar across the different categories of contagious illnesses, although it is only statistically significant for diarrhea/vomiting. The decrease in illness-related absence following the inspection seems to be mainly due to a decrease in other infections (e.g. fever, eye infections, impetigo, and chickenpox). The estimate for the fourth category shows no effect of the intervention. This is reassuring since we should not expect the intervention to affect illness that is not contagious.

Table 13: Estimated effects on absence due to different types of illness

\begin{tabular}{|c|c|c|c|c|}
\hline & $\begin{array}{c}\text { (1) } \\
\text { Upper } \\
\text { respiratory tract } \\
\text { infections } \\
\end{array}$ & $\begin{array}{c}\text { (2) } \\
\text { Diarrhea/ } \\
\text { vomiting }\end{array}$ & $\begin{array}{c}\text { (3) } \\
\text { Other infections: } \\
\text { fever, eye infections, } \\
\text { impetigo, chickenpox }\end{array}$ & $\begin{array}{c}\text { (4) } \\
\text { Non- } \\
\text { contagious } \\
\text { illness } \\
\end{array}$ \\
\hline Intervention & $\begin{array}{c}0.0225 \\
(0.0211)\end{array}$ & $\begin{array}{l}0.0223^{\star *} \\
(0.0105)\end{array}$ & $\begin{array}{c}0.0241 \\
(0.0197)\end{array}$ & $\begin{array}{c}-0.00994 \\
(0.00676)\end{array}$ \\
\hline Hygiene inspection & $\begin{array}{c}0.0225 \\
(0.0174)\end{array}$ & $\begin{array}{l}-0.0112 \\
(0.0107)\end{array}$ & $\begin{array}{c}-0.0508^{\star \star *} \\
(0.0177)\end{array}$ & $\begin{array}{l}-0.000406 \\
(0.00563)\end{array}$ \\
\hline $\begin{array}{l}\text { Observations } \\
\text { R-squared } \\
\text { Men of dep. variable } \\
\text { Relative effect intervention }{ }^{2} \\
\text { Relative effect inspection }{ }^{2}\end{array}$ & $\begin{array}{c}716,371 \\
0.401 \\
0.8374 \\
0.0269 \\
0.0269\end{array}$ & $\begin{array}{c}716,371 \\
0.283 \\
0.2046 \\
0.1090 \\
-0.0547\end{array}$ & $\begin{array}{c}716,371 \\
0.283 \\
0.4748 \\
0.0508 \\
-0.1070\end{array}$ & $\begin{array}{l}716,371 \\
0.160 \\
0.0835 \\
-0.1190 \\
-0.0049\end{array}$ \\
\hline $\begin{array}{l}\text { Controls for: } \\
\text { Child characteristics }^{3} \\
\text { Preschool controls } \\
\text { Parental controls } \\
\text { Preschool-spec. trends } \\
\text { Pres }\end{array}$ & $\begin{array}{l}\text { yes } \\
\text { yes } \\
\text { yes } \\
\text { no }\end{array}$ & $\begin{array}{c}\text { yes } \\
\text { yes } \\
\text { yes } \\
\text { no }\end{array}$ & $\begin{array}{l}\text { yes } \\
\text { yes } \\
\text { yes } \\
\text { no }\end{array}$ & $\begin{array}{l}\text { yes } \\
\text { yes } \\
\text { yes } \\
\text { no }\end{array}$ \\
\hline
\end{tabular}

Note: The regressions are estimated at the preschool level with each preschool weighted by the number of children enrolled. All regressions control for month-by-year and preschool fixed effects. ${ }^{1}$ The mean of the dep. variable is calculated among the untreated observations only. ${ }^{2}$ The relative effect is obtained by relating the estimate to the mean of the dependent variable. ${ }^{3}$ The child characteristics include exact age (in months), expected preschool grade, sex, and presence of older/younger siblings. ${ }^{4}$ The preschool controls include number of children at the preschool, average number of children in each section, and age composition among the children (see Table 1 for details). ${ }^{5}$ The parental characteristics include indicators for foreign background, each parent's age (3rd order polynomial), each parent's years of education (3rd order polynomial), indicators for whether each of the parents is a student, and controls for missing values for any of the variables. Robust standard errors, clustered on preschools, in parentheses. */**/*** denotes significance on the 10/5/1 percent level.

\footnotetext{
${ }^{33}$ In the digitalization of these data, observations with missing information on type of illness have been put in the first category since upper respiratory tract infections is the most common type of infection among small children. This could mean that this category is not as clean as the other. Moreover, there is no account of the extent of missing information.
} 


\subsubsection{Time-varying effects}

Finally, we have made some attempts to uncover whether the effect of the intervention varies over time. It is possible that preschools that have introduced stricter practices through the intervention (both with respect to hygiene and keeping contagious children at home) find it difficult to maintain these over time. Or, alternatively, the routines may become more established over time. To investigate whether the effect varies over time at the preschools, we have defined separate treatment indicators for different years after the intervention began. That is, Treated month 1-12 takes the value one during the first year of the intervention, and zero otherwise; Treated month 13-24 takes the value one during the second year of the intervention, and zero otherwise; and so on. ${ }^{34}$ Table 14 presents the average results at the preschool level from this analysis.

The first column shows results for the full sample using parents' use of TPB as the outcome. The estimates for all treatment indicators are close to zero and statistically insignificant. The estimates are generally small and statistically insignificant also for the smaller sample of preschools for which we have information on reported absence, regardless of whether we use number of days with TPB (col. 2) or number or days with reported absence due to illness as outcome (col.3). Hence, there are no indications of clear differences in effects over time.

\footnotetext{
${ }^{34}$ Note that the longer-run outcomes are only observed for the preschools that were exposed to the intervention early in your study period.
} 
Table 14: Estimated effects year by year at the preschool level

\begin{tabular}{|c|c|c|c|}
\hline & $\begin{array}{l}\text { (1) } \\
\begin{array}{l}\text { No. of TPB-days } \\
\text { (full sample) }\end{array}\end{array}$ & $\begin{array}{c}\text { (2) } \\
\text { No. of TPB-days } \\
\text { (sample with reported } \\
\text { presence/absence) }\end{array}$ & $\begin{array}{l}\text { (3) } \\
\text { No. of days with } \\
\text { reported illness-related } \\
\text { absence }\end{array}$ \\
\hline Treated month 1-12 & $\begin{array}{l}0.000819 \\
(0.00617)\end{array}$ & $\begin{array}{c}0.00501 \\
(0.00988)\end{array}$ & $\begin{array}{c}0.0107 \\
(0.0193)\end{array}$ \\
\hline Treated month 13-24 & $\begin{array}{c}-0.00203 \\
(0.00691)\end{array}$ & $\begin{array}{l}0.00365 \\
(0.0109)\end{array}$ & $\begin{array}{c}0.0232 \\
(0.0188)\end{array}$ \\
\hline Treated month 25-36 & $\begin{array}{c}-0.00292 \\
(0.00758)\end{array}$ & $\begin{array}{l}0.00232 \\
(0.0117)\end{array}$ & $\begin{array}{c}-0.0232 \\
(0.0199)\end{array}$ \\
\hline Treated month $37-48$ & $\begin{array}{c}0.00332 \\
(0.00915)\end{array}$ & $\begin{array}{c}0.0146 \\
(0.0144)\end{array}$ & $\begin{array}{c}-0.00568 \\
(0.0254)\end{array}$ \\
\hline Treated month 49-60 & $\begin{array}{c}0.00216 \\
(0.00990)\end{array}$ & $\begin{array}{l}0.00637 \\
(0.0152)\end{array}$ & $\begin{array}{c}-0.00333 \\
(0.0299)\end{array}$ \\
\hline $\begin{array}{l}\text { Observations } \\
\text { R-squared } \\
\text { Mean of dep. variable }\end{array}$ & $\begin{array}{c}2,587,860 \\
0.059 \\
0.4454\end{array}$ & $\begin{array}{c}716,371 \\
0.534 \\
1.4854\end{array}$ & $\begin{array}{c}716,371 \\
0.441 \\
0.5307\end{array}$ \\
\hline $\begin{array}{l}\text { Controls for: } \\
\text { Child characteristics }^{2} \\
\text { Preschool characteristics }^{3} \\
\text { Parental characteristics } \\
\text { Preschool-spec. trends } \\
\text { Prend }\end{array}$ & $\begin{array}{l}\text { yes } \\
\text { yes } \\
\text { yes } \\
\text { no }\end{array}$ & $\begin{array}{c}\text { yes } \\
\text { yes } \\
\text { yes } \\
\text { no } \\
\end{array}$ & $\begin{array}{c}\text { yes } \\
\text { yes } \\
\text { yes } \\
\text { no } \\
\end{array}$ \\
\hline \multicolumn{4}{|c|}{$\begin{array}{l}\text { Notes: Treatment is defined to take place } 12,24,36 \text { or } 48 \text { months before the actual start-up meeting. All regressions } \\
\text { control for month-by-year and preschool fixed effects. The child characteristics include exact age (in months), } \\
\text { expected preschool grade, sex, and presence of older/younger siblings. }{ }^{2} \text { The preschool controls include number of } \\
\text { children at the preschool, average number of children in each section, and age composition among the children (see } \\
\text { Table } 1 \text { for details). }{ }^{3} \text { The parental characteristics include indicators for foreign background, each parent's age (3rd } \\
\text { order polynomial), each parent's years of education (3rd order polynomial), indicators for whether each of the parents } \\
\text { is a student, and controls for missing values for any of the variables. Robust standard errors, clustered on preschools, } \\
\text { in parentheses. }{ }^{* * * * * *} \text { denotes significance on the } 10 / 5 / 1 \text { percent level. }\end{array}$} \\
\hline
\end{tabular}

\section{Concluding discussion}

We investigate the effects of a preschool health intervention with the explicit aim of reducing the number of infections among the children. The intervention involved an inspection of the preschool's hygiene practices and a lecture for the staff on how to prevent contagious illness. As a part of the interventions, preschools were also encouraged to use guidelines regarding recommended lengths of absence for different types of infections.

We find no reduction, on average, in children's illness-related absence due to the intervention. This conclusion holds regardless of whether we measure illness-related absence by parents' use of temporary parental benefits (TPB) or by reported absence from the preschools. It also holds across different age groups of preschool children, and for preschools with varying levels of TPB-use before the intervention. We do, however, find evidence of a small decline in the use of TPB for children enrolled in sections with 
relatively few children. A potential explanation could be that it is easier to implement and keep up strict hygiene practices in smaller groups of children.

A closer look at the underlying patterns in our data suggests that the zero average effect may be the sum of two opposing effects: an initial increase in absence due to illness following the start-up meeting, possibly caused by stricter guidelines regarding absence during infections. Given this initial increase, we find a decline in absence following the inspection of the preschool's hygiene practices and the lecture for the staff, which is in line with improved hygiene practices leading to less absence due to illness among the children.

Our finding that the hygiene intervention did not seem to reduce absence due to illness on average differs from the results in some previous evaluations of hygiene interventions at preschools in Sweden and Finland; see Lennel et al. (2008) and Uhari et al. (1999). We believe there are (at least) two important differences between the intervention studied here and the earlier mentioned ones. First, the other studies are based on data from smaller-scale randomized control trials, where compliance with the new hygiene practices have been more strictly monitored. It is possible that the proposed hygiene practices were followed less strictly in the intervention that we study. Second, we estimate the effect of a package of measures that, among other things, included guidelines regarding recommended length of absence for different types of infections. It is possible that the introduction of such guidelines could have caused parents to keep their children home longer, or more frequently, for a given level of illness. This means that it is possible that the intervention did improve the preschools' hygiene practices and thereby the children's health, even though we find no significant reduction in illness-related absence. 


\section{References}

Almond D and J Currie (2011), "Human capital development before age five”, Ed. O Ashenfelter and D Card. Handbook of Labor Economics 4 ch. 15: 1315-1486.

Baker, M, J Gruber, and K Milligan (2008), "Universal child care, maternal labor supply and family well-being”, Journal of Political Economy 116(4): 709-745.

Ball, T M, J C Holberg, M B Aldous, F D Martinez, A L Wright (2002), “Influence of attendance at day care on the common cold from birth through 13 years of age”, Archives of Pediatrics and Adolescent Medicine, 156: 121-126.

Berlinski, S, S Galiani, and P Gertler (2009), "The effect of pre-primary education on primary school performance”, Journal of Public Economics 93(1-2): 219-234.

Brady, MT (2005), “Infectious disease in pediatric out-of-home child care”, American Journal of Infection Control 33: 276-285.

de Hoog, M, R Venekamp, C van der Ent, A Schilder, E Sanders, R Damoiseaux, D Bogaert, C Uiterwaal, H Smit, P Bruijning-Verhagen (2014), ”Impact of early daycare on healthcare resource use related to upper respiratory tract infections during childhood: prospective WHISTLER cohort study”, BMC Medicine 12:107.

Dhuey, E (2011), “Who benefits from kindergarten? Evidence from the introduction of state subsidization”, Education Evaluation and Policy Analysis 33(1): 3-22.

Försäkringskassan (2014), Socialförsäkringen i siffror 2014, Stockholm.

Gormley, W, T Gayer, D Phillips, and B Dawson, (2005), “The effects of universal preK on cognitive development”, Developmental Psychology 41(6): 872-884.

Havnes, T and Mogstad, M (2011), "No child left behind: Subsidized child care and children's long-run outcomes”, American Economic Journal: Economic Policy 2 (May): 97-129.

Hedin, K, M Andre, S Mölstad, N Rodhe, and C Petersson (2006), "Infections in families with small children: Use of social insurance and healthcare", Scandinavian Journal of Primary Health Care 24:2: 98-103.

Huskins, WC (2000), "Transmission and control of infections in out-of-home child care”, Pediatric Infectious Disease Journal 19: 106-110. 
Lefebvre, P, P Merrigan, and F Roy-Desrosiers (2011), “Quebec’s childcare universal low fees policy 10 years after: Effects, costs, and benefits” CIRPEE Working Paper 11-01.

Lennell, A, S Kühlmann-Berenzon, P Geli, K Hedin, C Petersson, O Cars, K Mannerquist, L Burman and H Fredlund (2008), “Alcohol-based hand-disinfection reduced children's absence from Swedish day care centers” Acta Paediatrica 97: $1672-1680$.

Lu, N, M E Samuels, L Shi, S L Baker, S H Glover, J M Sanders (2004), “Child day care risks of common infectious diseases revisited" Child: Care, Health and Development 30(4):361-368.

National Agency for Education (Skolverket) (2014a), Barn och grupper i förskolan 15 oktober 2014, Table 2D, http://www.skolverket.se/statistik-och-utvardering/statistiki-tabeller/forskola/barn-och-grupper/barn-och-grupper-i-forskolan-15-oktober-20141.234046

National Agency for Education (2014b), Barn och personal i förskolan hösten 2014, http://www.skolverket.se/publikationer?id=3421

OECD (2014), Education at a Glance 2014: OECD Indicators, OECD Publishing.

Ruhm, C and J Waldfogel (2011). "Long-term effects of early childhood care and education”. IZA Discussion paper No. 6149.

Smittskydd Västra Götaland (2014), ”HYFS Slutrapport 206-2012”, http://www.vgregion.se/upload/Slutrapport\%20Hyfs\%2020141128.pdf

Uhari, M and M Möttönen (1999), “An open randomized controlled trial of infection prevention in child day-care centers”, The Pediatric Infectious Disease Journal 18: $672-677$.

Wald E R, N Guerra, and C Byers (1991), "Frequency and severity of infections in day care: Three-year follow-up” Journal of Pediatrics: 118(4): 509-514.

Wolfers, Justin (2006), “Did Unilateral Divorce Laws Raise Divorce Rates? A Reconciliation and New Results”, American Economic Review 96(5): 1802-1820. 
Willmott M, A Nicholson A, H Busse, G J MacArthur, S Brookes, and R Campbell (2015) "Effectiveness of hand hygiene interventions in reducing illness absence among children in educational settings: a systematic review and meta-analysis”, Arch Dis Child, doi:10.1136/archdischild- 2015-308875. 


\section{Appendix 1}

The analysis of the variation in illness-related absence across preschools in Section 3.2.3 is conducted as follows:

1) We calculate the difference between the actual number of TPB-days (TPB), and the predicted number estimated from a model with flexible monthly time controls (TPB_hat1).

2) We repeat the same procedure as in 1) but add individual background controls to the model, which generates TPB_hat2 and the difference between actual TPB and TPB_hat2.

3) We calculate TPB, TPB_hat1 and TPB_hat2 by year and preschool.

4) We plot different (weighted by number of children) parts of the distribution of the differences between $T P B$ and $T P B \_$hat1 and $T P B \_$hat2, respectively. 


\section{Appendix 2: Additional tables and figures}

Table A1: Number of days between different parts of the intervention

\begin{tabular}{lcccc}
\hline & Mean & St dev & $\begin{array}{c}\text { Min } \\
\text { (p1) }\end{array}$ & $\begin{array}{c}\text { Max } \\
\text { (p99) }\end{array}$ \\
\hline $\begin{array}{l}\text { No. of days between the start-up meeting and the } \\
\text { inspection of hygiene practices }\end{array}$ & 123.95 & 136.71 & 9 & 531 \\
$\begin{array}{l}\text { No. of days between the inspection of hygiene } \\
\text { practices and the lecture for the staff }\end{array}$ & 24.75 & 125.89 & 175 & 258 \\
\hline
\end{tabular}


Table A2: Heterogeneous effects. Comparing estimated effects across different outcomes

\begin{tabular}{|c|c|c|c|c|}
\hline & $\begin{array}{c}(1) \\
\text { Parents' use } \\
\text { of TPB }\end{array}$ & $\begin{array}{c}(2) \\
\text { Reported } \\
\text { absence due to } \\
\text { illness }\end{array}$ & $\begin{array}{c}(3) \\
\text { Parents' use } \\
\text { of TPB }\end{array}$ & $\begin{array}{c}\text { (4) } \\
\text { Reported } \\
\text { absence due to } \\
\text { illness }\end{array}$ \\
\hline A. Group size ${ }^{1}$ & Small & Small & Large & Large \\
\hline Intervention & $\begin{array}{c}0.0165 \\
(0.0189)\end{array}$ & $\begin{array}{c}0.0350 \\
(0.0354)\end{array}$ & $\begin{array}{l}-0.0205 \\
(0.0200)\end{array}$ & $\begin{array}{c}0.0205 \\
(0.0286)\end{array}$ \\
\hline $\begin{array}{l}\text { Observations } \\
\text { Unit of observation } \\
\text { R-square } \\
\text { Mean of dep. variable }^{4}\end{array}$ & $\begin{array}{c}210,044 \\
\text { section } \\
0.324 \\
0.409\end{array}$ & $\begin{array}{l}210,044 \\
\text { section } \\
0.345 \\
1.635\end{array}$ & $\begin{array}{c}331,341 \\
\text { section } \\
0.337 \\
0.530\end{array}$ & $\begin{array}{c}331,341 \\
\text { section } \\
0.374 \\
1.530\end{array}$ \\
\hline B. Age composition ${ }^{2}$ & Toddler & Toddler & Mixed/older & Mixed/older \\
\hline Intervention & $\begin{array}{c}0.0212 \\
(0.0253)\end{array}$ & $\begin{array}{c}0.0205 \\
(0.0377)\end{array}$ & $\begin{array}{l}-0.0265^{\star} \\
(0.0153)\end{array}$ & $\begin{array}{c}0.0151 \\
(0.0259)\end{array}$ \\
\hline $\begin{array}{l}\text { Observations } \\
\text { Unit of observation } \\
\text { R-square } \\
\text { Mean of dep. variable }\end{array}$ & $\begin{array}{l}210,985 \\
\text { section } \\
0.294 \\
0.602\end{array}$ & $\begin{array}{l}210,985 \\
\text { section } \\
0.314 \\
1.904\end{array}$ & $\begin{array}{c}330,400 \\
\text { section } \\
0.315 \\
0.350\end{array}$ & $\begin{array}{l}330,400 \\
\text { section } \\
0.281 \\
1.317\end{array}$ \\
\hline C. Initial hygiene practices ${ }^{3}$ & Good & Good & Poor & Poor \\
\hline Intervention & $\begin{array}{c}0.0373 \\
(0.0232)\end{array}$ & $\begin{array}{c}0.0440 \\
(0.0565)\end{array}$ & $\begin{array}{l}-0.0168 \\
(0.0226)\end{array}$ & $\begin{array}{l}-0.0172 \\
(0.0457)\end{array}$ \\
\hline $\begin{array}{l}\text { Observations } \\
\text { Unit of observation } \\
\text { R-square } \\
\text { Mean of dep. variable }\end{array}$ & $\begin{array}{c}139,137 \\
\text { preschool } \\
0.487 \\
0.567\end{array}$ & $\begin{array}{c}139,137 \\
\text { preschool } \\
0.423 \\
1.5200\end{array}$ & $\begin{array}{c}246,577 \\
\text { preschool } \\
0.551 \\
0.500\end{array}$ & $\begin{array}{c}246,577 \\
\text { preschool } \\
0.432 \\
1.5916\end{array}$ \\
\hline B. Level of TPB in 2005 & $<75$ percentile & $<75$ percentile & $>75$ percentile & $>75$ percentile \\
\hline Intervention & $\begin{array}{l}0.00611 \\
(0.0122)\end{array}$ & $\begin{array}{c}0.0319 \\
(0.0246)\end{array}$ & $\begin{array}{l}0.00772 \\
(0.0215)\end{array}$ & $\begin{array}{c}-0.0219 \\
(0.0380)\end{array}$ \\
\hline $\begin{array}{l}\text { Observations } \\
\text { Unit of observation } \\
\text { R-square } \\
\text { Mean of dep. variable }\end{array}$ & $\begin{array}{c}574,561 \\
\text { preschool } \\
0.542 \\
0.4628\end{array}$ & $\begin{array}{c}574,561 \\
\text { preschool } \\
0.443 \\
1.5517\end{array}$ & $\begin{array}{c}141,810 \\
\text { preschool } \\
0.475 \\
0.612\end{array}$ & $\begin{array}{c}141,810 \\
\text { preschool } \\
0.475 \\
1.6157\end{array}$ \\
\hline $\begin{array}{l}\text { Controls for: } \\
\text { Child characteristics }^{5} \\
\text { Preschool controls } \\
\text { Parental controls } \\
\text { Preschool-spec. trends } \\
\text { Prescol }\end{array}$ & $\begin{array}{c}\text { yes } \\
\text { yes } \\
\text { yes } \\
\text { no }\end{array}$ & $\begin{array}{c}\text { yes } \\
\text { yes } \\
\text { yes } \\
\text { no }\end{array}$ & $\begin{array}{l}\text { yes } \\
\text { yes } \\
\text { yes } \\
\text { no }\end{array}$ & $\begin{array}{c}\text { yes } \\
\text { yes } \\
\text { yes } \\
\text { no }\end{array}$ \\
\hline
\end{tabular}

Note: The regressions are estimated at the preschool section level (panel A-B) or preschool level (panel C-D) with each section/preschool weighted by the number of children enrolled. All regressions control for month-by-year and preschool section (panel A-B) or preschool fixed effects (panel C-D). ${ }^{1} \mathrm{~A}$ small group is defined as a group with less than 15 children. ${ }^{2}$ Toddler groups are groups with a median age below $3 .{ }^{3}$ Good hygiene is defined as scoring above average on the hygiene-index. ${ }^{4}$ The mean of the dep. variable is calculated for each sub-sample separately and among untreated observations only. ${ }^{5}$ The child characteristics include exact age (in months), sex, and presence of older/younger siblings. ${ }^{6}$ The preschool controls include number of children at the preschool, average number of children in each section, and age composition among the children (see Table 1 for details). 7The parental characteristics include indicators for foreign background, each parent's age (3rd order polynomial), each parent's years of education (3rd order polynomial), indicators for whether each of the parents is a student, and controls for missing values for any of the variables. Robust standard errors, clustered on preschools, in parentheses. $* / * * / * * *$ denotes significance on the 10/5/1 percent level. 
Table A3: Estimated effect of different parts of the intervention. Comparing the estimated effects across different outcomes

\begin{tabular}{|c|c|c|c|}
\hline & $\begin{array}{c}\text { (1) } \\
\text { No. of TPB-days }\end{array}$ & $\begin{array}{l}\text { (2) } \\
\begin{array}{l}\text { No. of days with illness- } \\
\text { related absence }\end{array} \\
\end{array}$ & $\begin{array}{c}\text { (3) } \\
\text { Share of days absent due to } \\
\text { illness among scheduled days }\end{array}$ \\
\hline Intervention & $\begin{array}{l}0.0269^{\star} \\
(0.0138)\end{array}$ & $\begin{array}{l}0.0595^{\star \star} \\
(0.0278)\end{array}$ & $\begin{array}{l}0.00401^{* *} \\
(0.00175)\end{array}$ \\
\hline Hygiene inspection & $\begin{array}{l}-0.0292^{\star *} \\
(0.0120)\end{array}$ & $\begin{array}{l}-0.0399^{*} \\
(0.0239)\end{array}$ & $\begin{array}{l}-0.00188 \\
(0.00152)\end{array}$ \\
\hline Observations & 716,371 & 716,371 & 716,371 \\
\hline R-squared & 0.535 & 0.442 & 0.469 \\
\hline Mean of dep.variable ${ }^{1}$ & 0.4947 & 1.5459 & 0.1014 \\
\hline $\begin{array}{l}\text { Relative effect } \\
\text { intervention }^{2}\end{array}$ & 0.0544 & 0.0385 & 0.0395 \\
\hline Relative effect inspection ${ }^{2}$ & -0.0590 & -0.0258 & -0.0185 \\
\hline \multicolumn{4}{|l|}{ Controls for: } \\
\hline Child characteristics $^{3}$ & yes & yes & yes \\
\hline Preschool characteristics ${ }^{4}$ & yes & yes & yes \\
\hline Parental characteristics ${ }^{5}$ & yes & yes & yes \\
\hline Preschool-spec. trends & no & no & no \\
\hline \multicolumn{4}{|c|}{$\begin{array}{l}\text { Note: The regressions are estimated at the preschool level with each preschool weighted by the number of children } \\
\text { enrolled. All regressions control for month-by-year and preschool fixed effects. }{ }^{1} \text { The mean of the dep. variable is } \\
\text { calculated among the untreated observations only. }{ }^{2} \text { The relative effect is obtained by relating the estimate to the mean } \\
\text { of the dependent variable. }{ }^{3} \text { The child characteristics include: exact age (in months); expected preschool grade; sex; } \\
\text { and presence of older/younger siblings. }{ }^{4} \text { The preschool controls include: number of children at the preschool; average } \\
\text { number of children in each section; and age composition among the children (see Table } 1 \text { for details). }{ }^{5} \text { The parental } \\
\text { characteristics include: indicators for foreign background; each parent's age (3rd order polynomial); each parent's } \\
\text { years of education (3rd order polynomial); indicators for whether each of the parents is a student; and controls for } \\
\text { missing values for any of the variables. Robust standard errors, clustered on preschools, in parentheses. */**/*** } \\
\text { denotes significance on the } 10 / 5 / 1 \text { percent level. }\end{array}$} \\
\hline
\end{tabular}

IFAU - Illness-related absence among preschool children 
Figure A1: Average number of days that parents use temporary parental benefit (TPB) per month for children in different preschool grades, depending on group size
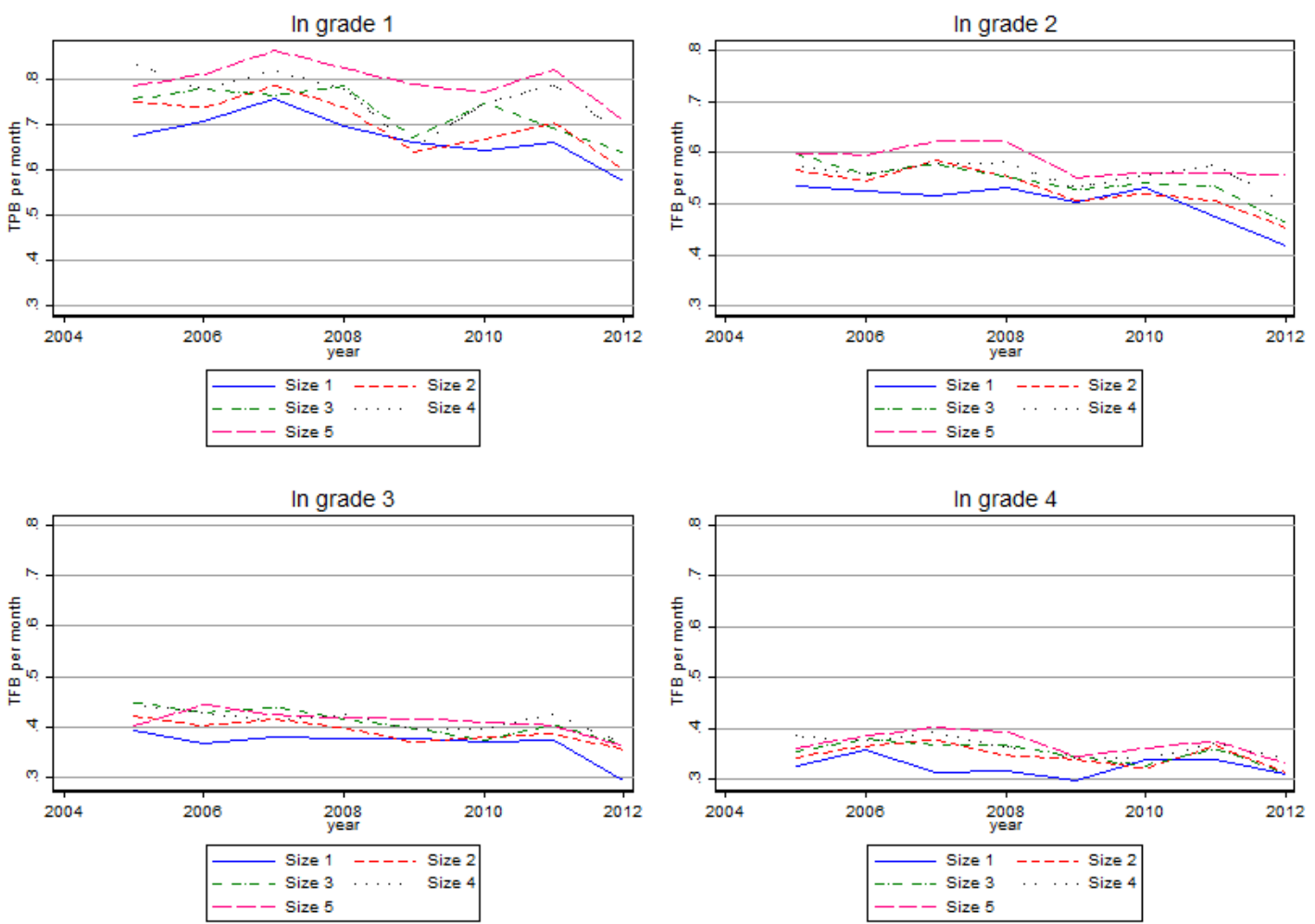

Note: "Size 1" denotes the smallest groups and "size 5" the largest. 
Figure A2: Average number of days that parents use temporary parental benefit (TPB) per month for children in different preschool grades, depending on age composition in the group
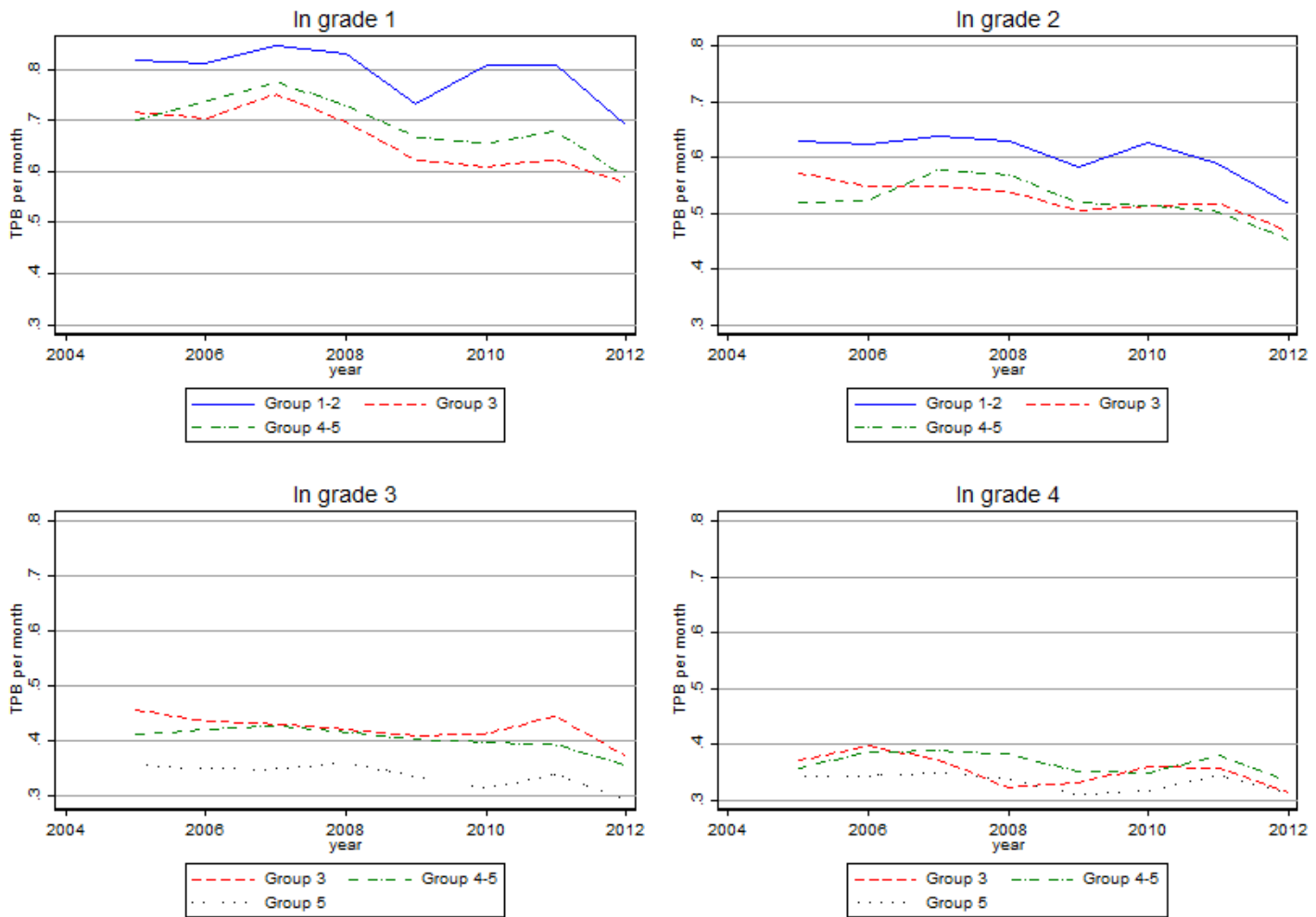

Note: The age composition is defined as the median age in years (rounded to the nearest integer) within the group:" p50<3" are children aged 1-2; "p50=3" are children with median age 3; "p50>3 \& p50<5" are children with median age above 3 but less than 5 and "p50=5” are children with median age 5 . 